Article

\title{
Optimal Design of an Isolated Hybrid Microgrid for Enhanced Deployment of Renewable Energy Sources in Saudi Arabia
}

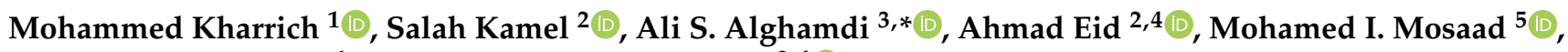 \\ Mohammed Akherraz ${ }^{1}$ and Mamdouh Abdel-Akher ${ }^{2,4}{ }_{(D)}$ \\ 1 Department of Electrical Engineering, Mohammadia School of Engineers, Mohammed V University, \\ Ibn Sina Street P.B. 765, Rabat 10090, Morocco; mohammedkharrich@research.emi.ac.ma (M.K.); \\ akherraz@emi.ac.ma (M.A.) \\ 2 Department of Electrical Engineering, Faculty of Engineering, Aswan University, Aswan 81542, Egypt; \\ skamel@aswu.edu.eg (S.K.); ahmadeid@aswu.edu.eg (A.E.); mabdelakher@ieee.org (M.A.-A.) \\ 3 Department of Electrical Engineering, College of Engineering, Majmaah University, \\ Majmaah 11952, Saudi Arabia \\ 4 Department of Electrical Engineering, Unaizah College of Engineering, Qassim University, \\ Unaizah 56453, Saudi Arabia \\ 5 Department of Electrical and Electronic Engineering, Yanbu Industrial College, Yanbu 46452, Saudi Arabia; \\ habibm@rcyci.edu.sa \\ * Correspondence: aalghamdi@mu.edu.sa
}

Citation: Kharrich, M.; Kamel, S.; Alghamdi, A.S.; Eid, A.; Mosaad, M.I.; Akherraz, M.; Abdel-Akher, M. Optimal Design of an Isolated Hybrid Microgrid for Enhanced Deployment of Renewable Energy Sources in Saudi Arabia. Sustainability 2021, 13, 4708. https://doi.org/10.3390/ su13094708

Academic Editors:

Alberto-Jesus Perea-Moreno and Hwachang Song

Received: 22 March 2021

Accepted: 16 April 2021

Published: 22 April 2021

Publisher's Note: MDPI stays neutral with regard to jurisdictional claims in published maps and institutional affiliations.

Copyright: (c) 2021 by the authors. Licensee MDPI, Basel, Switzerland. This article is an open access article distributed under the terms and conditions of the Creative Commons Attribution (CC BY) license (https:// creativecommons.org/licenses/by/ $4.0 /)$.

\begin{abstract}
Hybrid microgrids are presented as a solution to many electrical energetic problems. These microgrids contain some renewable energy sources such as photovoltaic (PV), wind and biomass, or a hybrid of these sources, in addition to storage systems. Using these microgrids in electric power generation has many advantages such as clean energy, stability in supplying power, reduced grid congestion and a new investment field. Despite all these microgrids advantages, they are not widely used due to some economic aspects. These aspects are represented in the net present cost (NPC) and the levelized cost of energy (LCOE). To handle these economic aspects, the proper microgrids configuration according to the quantity, quality and availability of the sustainable source of energy in installing the microgrid as well as the optimal design of the microgrid components should be investigated. The objective of this paper is to design an economic microgrid system for the Yanbu region of Saudi Arabia. This design aims to select the best microgrid configuration while minimizing both NPC and LCOE considering some technical conditions, including loss of power supply probability and availability index. The optimization algorithm used is Giza Pyramids Construction (GPC). To prove the GPC algorithm's effectiveness in solving the studied optimization problem, artificial electric field and grey wolf optimizer algorithms are used for comparison purposes. The obtained results demonstrate that the best configuration for the selected area is a PV/biomass hybrid microgrid with a minimum NPC and LCOE of $\$ 319,219$ and $\$ 0.208 / \mathrm{kWh}$, respectively.
\end{abstract}

Keywords: microgrid design; hybrid microgrid system; optimization of power systems; Giza Pyramids Construction algorithm

\section{Introduction}

The depletion of fuel, environmental problems and the danger of nuclear use oblige the international community to adopt renewable energy resources, mainly the isolated mode in the non-electrified areas where the extension of the grid is costly, and the power losses are very high. Otherwise, the intermittence of the renewable resources is managed using hybrid systems such as PV and wind, which are considered complementary.

The hybrid microgrid systems (HMGs) become essential electrification of rural areas. The hybrid renewable energy system (HRES) is investigated and proposed in many studies (e.g., [1-7]), which introduce all necessary information to design isolated HRES. The authors of [1] presented the design and financing of a microgrid on a small Koh Jik Island 
in Thailand. HOMER is used to provide techno-economic insights. Likewise, a comparison of lead-acid and lithium-ion battery technologies and their impact on LCOE and the renewable fraction is investigated. On the other hand, the authors of [2] presented a review of the energy system model characteristics and the existing tools to optimize the multienergy system. The authors of [3] presented a review of the recent optimization approaches to resolving the operation cost and reducing the total network losses. The authors of [4] outlined a review of the system optimization and energy management strategies taking into account the sources of PV, wind turbine and fuel cell. In another research [5], a survey of the microgrid development in the seaport areas is outlined. Similarly, the authors of [6] presented a review of the major issues in the adoption of HRES, as well as a survey of the different renewable sources which can be integrated for both isolated and grid-connected modes. In addition, the authors of [7] presented a review containing the optimization tools, constraints and battery types in the HRES design.

The desert of Saudi Arabia is a crucial region for these kinds of projects. Saudi Arabia has excellent meteorological conditions, which explains the important number of studies in this country. In [8], a recent methodology is developed based on social spider optimizer (SSO). The goal is to determine the optimal sizing of a microgrid containing PV, wind, diesel and battery in Aljouf Region. The study focused on three configurations: $\mathrm{PV} /$ battery/diesel, wind/battery/diesel and PV/wind/battery/diesel. In addition, several algorithms are used to optimize the cost of energy, respecting the Loss of Power Supply Probability (LPSP) as a technical factor. In [9], the PV/FC/battery system design and a sensitivity analysis study are presented. The project is to feed a small community of the city NEOM in Saudi Arabia. In Yanbu [10], the wind/PV microgrid is analyzed, and the cost of energy is investigated. The technical and economic aspects analyses are performed using HOMER software, considering both the unmet electric load and the excess electricity. In [11], four cities in the Kingdom of Saudi Arabia (Riyadh, Hafar Albatin, Sharurah and Yanbu) are selected for a study which aims to feed a community load demand. The proposed system is a grid-connected PV/wind, where the design is investigated using HOMER software considering technical and economic analyses.

The design of HMGs-renewable energy systems needs to define the suitable configuration for each localization. In [12], three configurations are proposed, namely PV/wind/diesel/ battery, PV/tidal/biomass/battery and PV/biomass, in seven areas in Morocco. Barbaro et al. [13] proposed an optimized design of a system containing wind, PV, geothermal, battery and diesel generators as backup. The project considered the technical and financial feasibility for Faial Island in the Azores archipelago. The PV/wind/battery/diesel HMG system is still the most adapted in the world for its power synergy, as well as the use of the battery and diesel as a back-up [14-17]. The authors of [14] proposed this HMG in Rabat. The authors of [15] presented the same microgrid to feed a residential area in Kasuga City, Fukuoka, Japan. The authors of [16] proposed the same HMG design in Rabat, Morocco and Baghdad, Iraq. The project systems were compared by their levelized cost of energy. In Benin country [17], it was found that PV/diesel/battery microgrid system is the more suitable for feeding off-grid rural communities. An investigation of the economic feasibility of the microgrid based on renewable sources to avoid the strong dependency on fossil fuel on the Lampedusa island in Italy is proposed and investigated in [18]. At the same time, the authors of [19] presented several technologies to integrate the micro resources and the storage systems. Moreover, new DC-bus signaling is proposed and implemented to control the distributed decentralized systems. The authors of [20] presented a study to identify the optimal configuration of components on Pantelleria Island and the sizing and operating schedule that minimize the annual cost. The authors of [21] presented techno-economic feasibility of the renewable energy systems using HOMER Pro, which consider hydrogen as a storage energy system. The authors of [22] proposed an efficient approach to simulate a DC-DC converter that is connected to the PV device.

Many difficulties and challenges in the RES design and sizing need to be balanced between the economic and technical aspects. The literature presents many traditional and 
recent algorithms to reach these objectives, which proved to provide their feasibility to find the optimal solution. Khan and Javaid [23] proposed a hybrid algorithm named the JLBO composed of Jaya and teaching-learning-based optimization (TLBO), dedicated to finding optimal PV/WT/battery sizing for a microgrid system. Makhdoomi and Askarzadeh [24] proposed a hybrid of CSA and the adaptive chaotic awareness probability algorithms called CSAAC-AP to optimize PV/diesel/PHS microgrid system operation. Kharrich et al. [25] proposed an improvement of the Bonobo Optimizer (BO), using the quasi-oppositional technique for resolving the microgrid design problem that is based on PV, wind, battery, diesel and biomass, with four configurations, and the case study was Aswan, Egypt. The algorithm is compared with BO, Harris Hawks Optimization (HHO), Algorithm of Artificial Electric Field (AEFA) and IWO algorithms. Abo-Elyousr and Nozhy [26] developed a biobjective ant colony algorithm (BOACA) for the optimal size of several configurations of hybrid microgrids. A comprehensive summary of previous work considering microgrid design and operation is listed in Table 1.

In this paper, microgrid design and power management are investigated for two configurations, $\mathrm{PV} /$ biomass and $\mathrm{PV} /$ wind/diesel/battery, to feed an isolated area in the Yanbu region of Saudi Arabia. The main objective of this paper is minimizing NPC, considering technical factors. The optimization is applied using many meta-heuristic algorithms such as the Giza Pyramids Construction (GPC), AEFA and Grey Wolf Optimizer (GWO). In summary, the paper presents four contributions:

- Optimal design of the microgrid system feeding a load in the Yanbu region in Saudi Arabia

- Proposing and analyzing two configurations of microgrid systems considering their technical and operational features

- Presenting the optimal design operation of the hybrid renewable microgrid system by selecting suitable renewable sources to meet the required objectives and constraints

- Investigation and implementation of a recent GPC optimization algorithm and compared it with other algorithms

The mathematical modeling of renewable systems (PV and wind), conventional diesel and battery systems are presented in Section 2. Section 3 presents the mathematical formulation of the objective function. Section 4 presents the mathematical modeling of GPC optimization algorithm. Section 5 presents the case study. Section 6 presents the results and discussions. Finally, Section 7 presents the main conclusions. 
Table 1. Summary of previous work.

\begin{tabular}{|c|c|c|c|c|c|c|c|}
\hline Reference & Year & Microgrid System & Location & Algorithm/Tool & Objective Function & Strength & Weakness \\
\hline Fathy et al. [8] & 2020 & $\mathrm{PV} /$ wind/battery/diesel & Sakaka, Aljouf, Saudi Arabia & $\begin{array}{l}\text {-SSO-WOA-ALO } \\
\text {-MVO-GWO }\end{array}$ & $\mathrm{COE}$ & Detailed study. & $\begin{array}{l}\text { The constraint factors } \\
\text { are limited }\end{array}$ \\
\hline Rezk et al. [9] & 2020 & $\mathrm{PV} / \mathrm{FC} /$ battery & NEOM, Saudi Arabia & HOMER & $\begin{array}{l}-\mathrm{NPC} \\
-\mathrm{COE}\end{array}$ & $\begin{array}{l}\text { Present the effect of tilt angle } \\
\text { and derating factor variation } \\
\text { on COE }\end{array}$ & $\begin{array}{l}\text { The study should be enhancec } \\
\text { by a comparison of HOMER } \\
\text { with other algorithms }\end{array}$ \\
\hline Ramli et al. [10] & 2016 & wind/PV & Yanbu, Saudi Arabia & HOMER & $\begin{array}{l}\text {-NPC-COE-unmet } \\
\text { demand of the electric } \\
\text { load-excess electricity }\end{array}$ & $\begin{array}{l}\text { Consider the unmet electric } \\
\text { load demand and the } \\
\text { excess electricity }\end{array}$ & $\begin{array}{l}\text { The study does not take the } \\
\text { reliability factor as an } \\
\text { objective or constraint }\end{array}$ \\
\hline Kharrich et al. [12] & 2021 & $\mathrm{PV} /$ wind/diesel/battery & Dakhla, Morocco & $\begin{array}{l}\text {-HHO-AEFA-GWO } \\
\text {-STOA-EO }\end{array}$ & NPC & $\begin{array}{l}\text { Apply a new } \\
\text { meta-heuristic algorithm }\end{array}$ & $\begin{array}{l}\text { The study does not consider } \\
\text { uncertainty }\end{array}$ \\
\hline Barbaro et al. [13] & 2019 & $\mathrm{PV} /$ wind/geothermal/diesel & Faial Island, Portugal & $\begin{array}{l}\text { Unit Commitment } \\
\text { (UC) algorithm }\end{array}$ & NPV & $\begin{array}{l}\text { Develop a new } \\
\text { simulation model }\end{array}$ & $\begin{array}{l}\text { The power management is } \\
\text { not shown }\end{array}$ \\
\hline $\begin{array}{l}\text { Yoshida, and } \\
\text { Farzaneh [15] }\end{array}$ & 2020 & $\mathrm{PV} /$ wind/battery/diesel & Kasuga, Japan & PSO & Total cost of system & $\begin{array}{l}\text { Use the least-cost } \\
\text { perspective approach }\end{array}$ & $\begin{array}{l}\text { The convergence curve of the } \\
\text { minimization of the objective } \\
\text { function is not presented }\end{array}$ \\
\hline Elkadeem et al. [16] & 2019 & $\begin{array}{l}\text {-PV/WT/DG1/DG2/battery } \\
\text {-PV/WT/DG1/battery } \\
\text {-PV/DG1/DG2/battery } \\
\text {-WT/DG1/DG2/battery } \\
\text {-DG1/DG2 }\end{array}$ & Dongola, Sudan & HOMER Pro & NPC & $\begin{array}{l}\text { Provide a comprehensive } \\
\text { feasibility analysis to feed the } \\
\text { electricity of agricultural and } \\
\text { irrigation areas. }\end{array}$ & $\begin{array}{l}\text { A meta-heuristic algorithm Is } \\
\text { not applied and compared to } \\
\text { HOMER Pro }\end{array}$ \\
\hline Odou et al. [17] & 2019 & PV/diesel/battery & Alibori, Benin & HOMER software & NPC & $\begin{array}{l}\text { Analyze the techno-economic } \\
\text { feasibility of hybrid system } \\
\text { with case study in } \\
\text { rural electrification }\end{array}$ & $\begin{array}{l}\text { The results are obtained by } \\
\text { HOMER only and not } \\
\text { compared with any } \\
\text { other algorithm }\end{array}$ \\
\hline $\begin{array}{l}\text { Khan and } \\
\text { Javaid [23] }\end{array}$ & 2020 & $\mathrm{PV} /$ wind/battery & Rafsanjan, Iran & $\begin{array}{l}\text {-Jaya-TLBO-JLBO } \\
\text {-GA }\end{array}$ & TAC & Propose a hybrid JLBO & $\begin{array}{l}\text { The renewable fraction is not } \\
\text { considered as an objective } \\
\text { function or constraints }\end{array}$ \\
\hline $\begin{array}{l}\text { Makhdoomi and } \\
\text { Askarzadeh [24] }\end{array}$ & 2020 & $\mathrm{PV} /$ diesel/PHS & Adrar, Algeria & $\begin{array}{l}\text {-GA-PSO-CSA } \\
\text {-CSAAC-AP }\end{array}$ & Fuel consumption & $\begin{array}{l}\text { Propose modified version of } \\
\text { the crow search } \\
\text { optimization algorithm }\end{array}$ & $\begin{array}{l}\text { The operation time of the } \\
\text { study is only } 24 \mathrm{~h}\end{array}$ \\
\hline
\end{tabular}


Table 1. Cont.

\begin{tabular}{|c|c|c|c|c|c|c|c|}
\hline Reference & Year & Microgrid System & Location & Algorithm/Tool & Objective Function & Strength & Weakness \\
\hline Kharrich et al. [25] & 2020 & $\begin{array}{l}\text {-PV/wind/diesel/battery } \\
\text {-PV/biomass } \\
\text {-PV/diesel/battery } \\
\text {-wind/diesel/battery }\end{array}$ & Aswan, Egypt & $\begin{array}{l}\text {-QOBO-BO } \\
\text {-HHO-AEFA-IWO }\end{array}$ & NPC & $\begin{array}{l}\text { Propose an algorithm: } \\
\text { Quasi-Oppositional } \\
\text { BO (QOBO) }\end{array}$ & $\begin{array}{l}\text { The uncertainty of the } \\
\text { renewable sources is } \\
\text { not considered }\end{array}$ \\
\hline $\begin{array}{l}\text { Abo-Elyousr and } \\
\text { Nozh [26] }\end{array}$ & 2018 & $\mathrm{PV} /$ wind/biomass/NGFC/NGT & $\begin{array}{l}\text { Kharga, Egypt } \\
\text { Saint Katherine, Egypt } \\
\text { Qussair, Egypt }\end{array}$ & $\begin{array}{l}\text {-BOACA-GA } \\
\text {-PSO-HOMER }\end{array}$ & $\begin{array}{l}\text {-COE } \\
\text {-GHG }\end{array}$ & $\begin{array}{l}\text { Develop the BOACA } \\
\text { algorithm to find } \\
\text { optimal HMG }\end{array}$ & LPSP results are not presented \\
\hline $\begin{array}{l}\text { Heydari and } \\
\text { Askarzadeh [27] }\end{array}$ & 2016 & PV/biomass & Kerman, Iran & HSA & NPC & $\begin{array}{l}\text { Show the limits of HOMER } \\
\text { compared to } \\
\text { meta-heuristic algorithm }\end{array}$ & $\begin{array}{l}\text { It does not provide a } \\
\text { comparison of the } \\
\text { HS algorithm }\end{array}$ \\
\hline Guangqian et al. [28] & 2018 & $\begin{array}{l}\text {-PV/diesel/battery } \\
\text {-Wind/diesel/battery } \\
\text {-Wind/PV/diesel/battery }\end{array}$ & Khorasan, Iran & $\begin{array}{l}\text {-HSA-SAA } \\
\text {-HHSSAA }\end{array}$ & LCC & $\begin{array}{l}\text { Propose hybrid } \\
\text { meta-heuristic algorithm to } \\
\text { size a } \\
\text { grid-independent system }\end{array}$ & $\begin{array}{l}\text { The reliability is } \\
\text { not considered }\end{array}$ \\
\hline Sawle et al. [29] & 2018 & $\begin{array}{l}\text {-PV/biomass/diesel/battery } \\
\text {-PV/diesel/battery } \\
\text {-Wind/biomass/diesel/battery } \\
\text {-Wind/diesel/battery } \\
\text {-PV/wind/diesel/battery } \\
\text {-PV/wind/biomass/diesel/battery }\end{array}$ & Barwani, India & $\begin{array}{l}\text {-GA-PSO-BFPSO } \\
\text {-TLBO }\end{array}$ & $\begin{array}{l}\text { Sum of } \\
\text { several objectives }\end{array}$ & Consider the social aspect & Uncertainty is not considered \\
\hline Ramli et al. [30] & 2018 & $\mathrm{PV} /$ wind/diesel/battery & & MOSaDE & -COE-LPSP & Clear study & $\begin{array}{l}\text { There is not comparison with } \\
\text { a multi-objective algorithm }\end{array}$ \\
\hline
\end{tabular}




\section{Mathematical Modeling}

In this case study, two configurations of the HMG systems are presented. The systems are composed of PV, wind, diesel, biomass and battery systems, as presented in Figure 1. The first configuration considers the PV/biomass microgrid system with the power management strategy presented in Figure 2. The second configuration considers the PV/wind/diesel/battery system with the power management shown in Figure 3. The main sequence of the microgrid operation is as follows:

- The PV and wind turbine supply energy as a pillar of the system.

- The battery operates when there is a shortage of power from renewable sources.

- The diesel generator works and supplies power when the battery is at its min SOC.

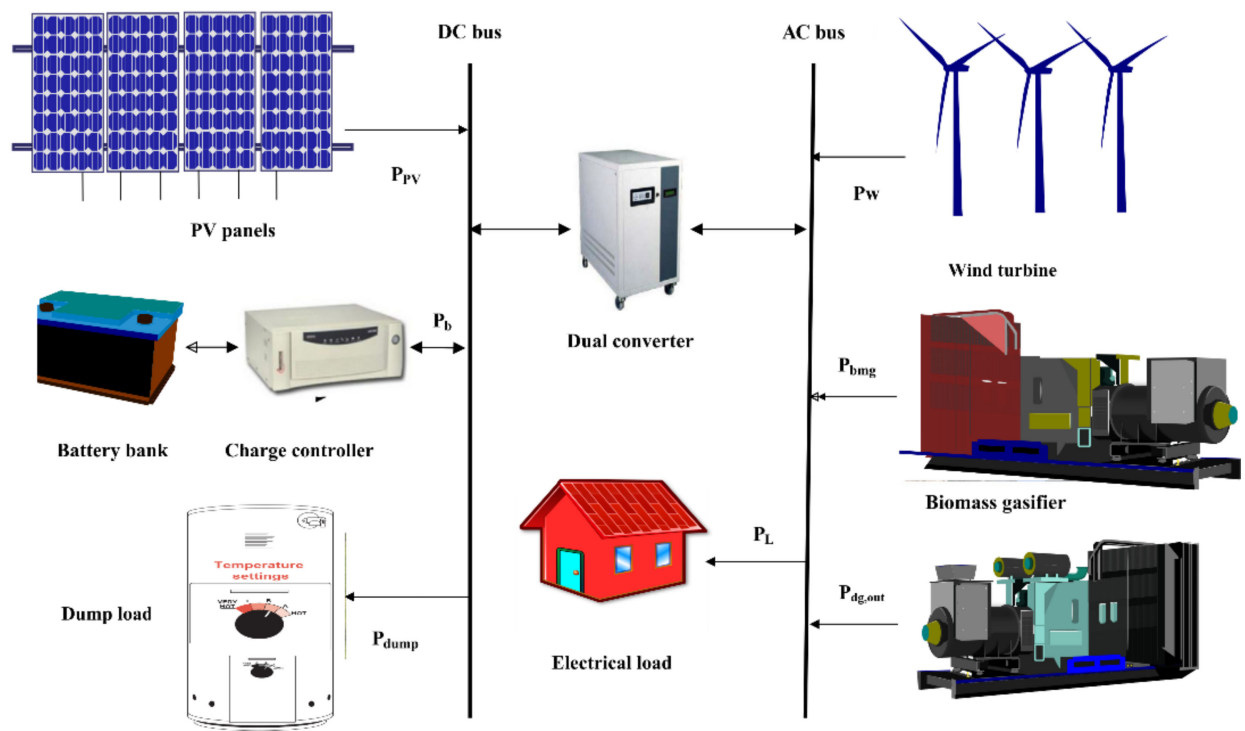

Figure 1. Components of the microgrid systems.

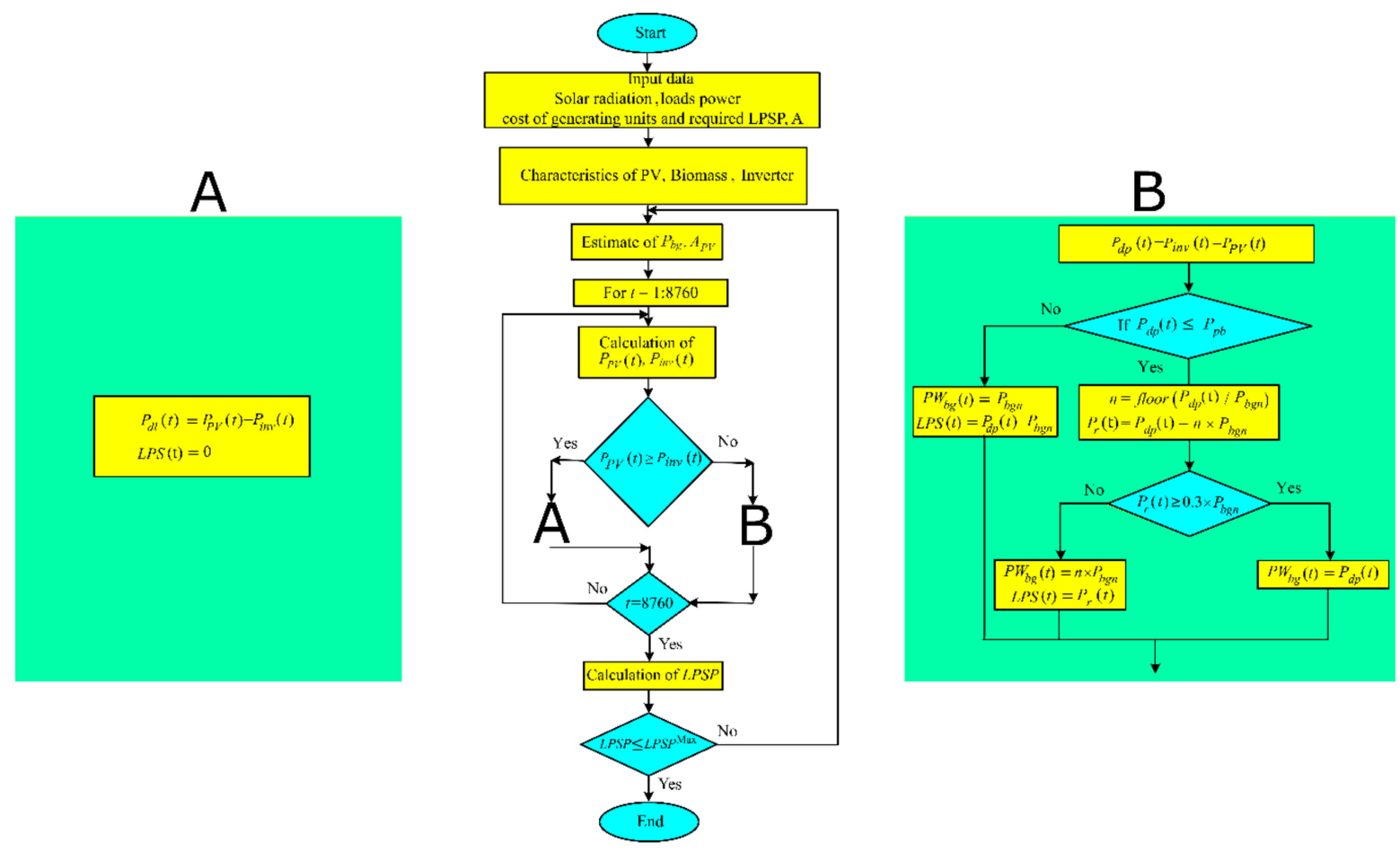

Figure 2. Management strategy of the PV/biomass system. 
A

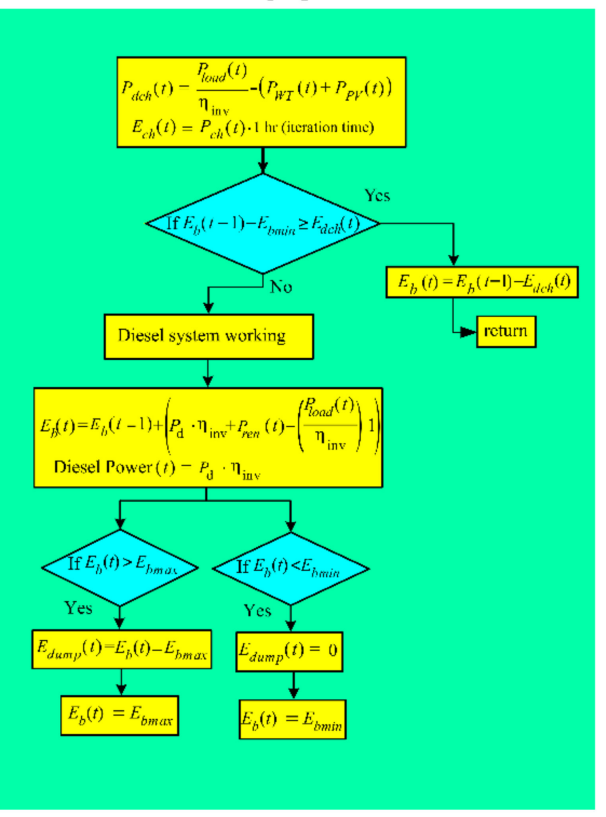

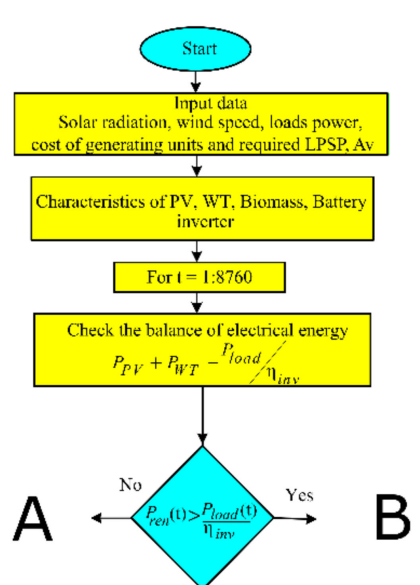

$\mathrm{B}$

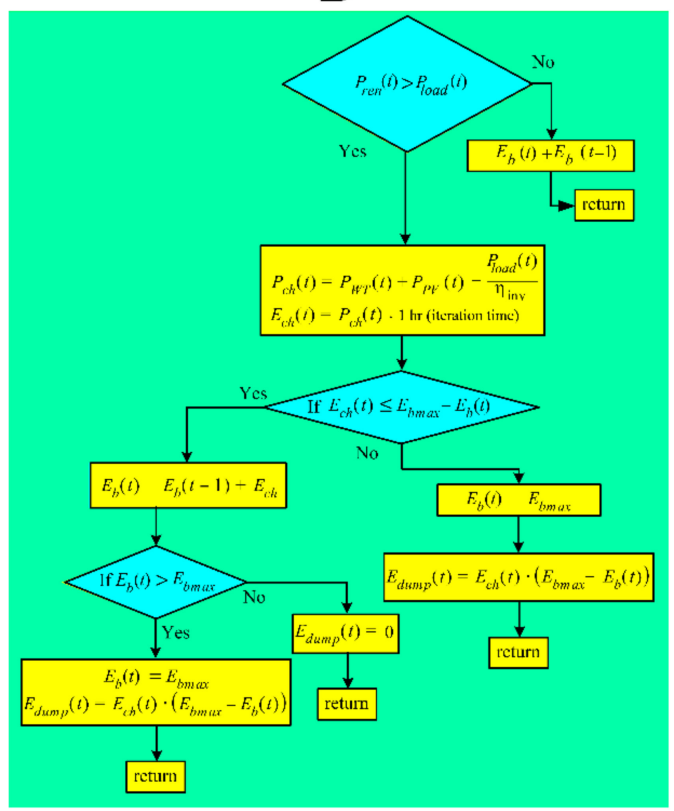

Figure 3. Management strategies of the PV/wind/diesel/battery microgrid system.

\subsection{PV Modeling}

The power of the PV panel can be represented as [27]:

$$
P_{p v}=I(t) \times \eta_{p v}<t>\times A_{p v}
$$

where $I$ represents solar irradiation, $A_{p v}$ represents the area of $P V$ panel and $\eta_{p v}$ represents the efficiency of the $P V$ system, which is calculated by:

$$
\eta_{p v}(t)=\eta_{r} \times \eta_{t} \times\left[1-\beta \times\left(T_{a}<t>-T_{r}\right)-\beta \times I<t>\times\left(\frac{N O C T-20}{800}\right) \times\left(1-\eta_{r} \times \eta_{t}\right)\right]
$$

where NOCT represents nominal operating of the cell temperature $\left({ }^{\circ} \mathrm{C}\right), \eta_{r}$ represents the reference efficiency, $\eta_{t}$ represents MPPT equipment efficiency, $\beta$ is temperature coefficient, $T_{a}$ represents ambient temperature $\left({ }^{\circ} \mathrm{C}\right)$ and $T_{r}$ represents cell reference temperature $\left({ }^{\circ} \mathrm{C}\right)$.

\subsection{Wind Generator Modeling}

The wind power depends on wind speed, which can be presented as [28]:

$$
P_{\text {wind }}= \begin{cases} & 0, V<t>\leq V_{c i}, V<t>\geq V_{c o} \\ a \times V<t>^{3}-b \times \quad & P_{r}, V_{c i}<V<t><V_{r} \\ & P_{r}, V_{r} \leq V<t><V_{c o}\end{cases}
$$

where $V$ represents wind speed; $P_{r}$ represents wind rated power; $V_{c i}, V_{c o}$ and $V_{r}$ are cut-in, cut-out and rated wind speeds, respectively; and a and $\mathrm{b}$ represent two constants that are calculated as:

$$
\left\{\begin{array}{l}
a=P_{r} /\left(V_{r}^{3}-V_{c i}{ }^{3}\right) \\
b=V_{c i}{ }^{3} /\left(V_{r}^{3}-V_{c i}{ }^{3}\right)
\end{array}\right.
$$

The rated power of wind is calculated as:

$$
P_{r}=\frac{1}{2} \times \rho \times A_{\text {wind }} \times C_{p} \times V_{r}^{3}
$$

where $\rho$ represents the air density, $A_{\text {wind }}$ represents the wind turbine swept area and $C_{p}$ represents the max power coefficient, which is limited between $0.25 \%$ and $0.45 \%$. 


\subsection{Biomass System Modeling}

The biomass produces power as [29]:

$$
P_{B M}=\frac{\text { Total }_{b i o} \times 1000 \times C V_{b i o} \times \eta_{b i o}}{8760 \times O_{\text {time }}}
$$

where Total ${ }_{b i o}$ is the total organic material of biomass which is from the date palm waste, $C V_{b i o}$ represents the calorific value of the organic material $(\approx 20 \mathrm{MJ} / \mathrm{kg}), \eta_{b i o}$ is the biomass efficiency and $O_{\text {time }}$ is the operating hour for each day. The procedure of converting the biomass to electricity is presented in Figure 4.

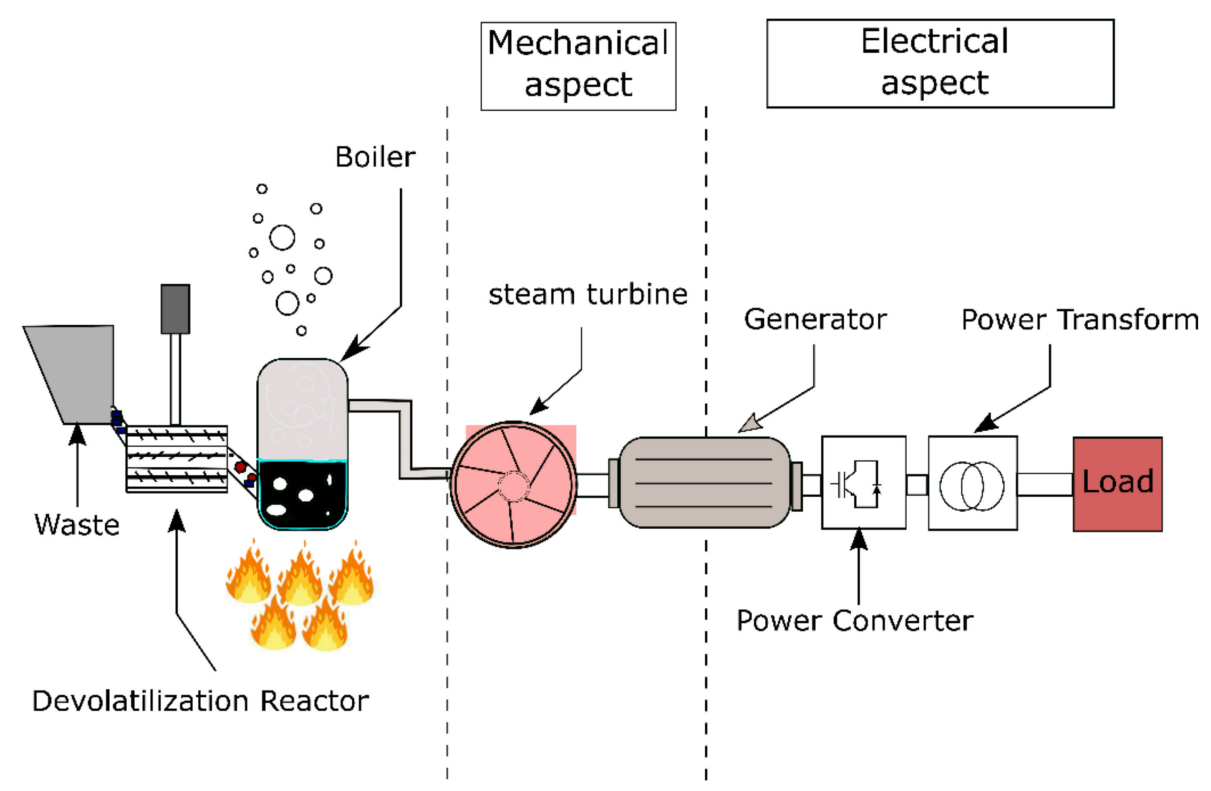

Figure 4. Energy conversion procedure of the biomass system.

\subsection{Diesel Generator System Modeling}

The rated power of diesel generator $\left(P_{d g}\right)$ is represented as [30]:

$$
P_{d g}=\frac{F_{d g}<t>-A_{g} \times P_{d g, o u t}}{B_{g}}
$$

where $F_{d g}$ is fuel consumption, $P_{d g, o u t}$ is the output power and $A_{g}$ and $B_{g}$ are two constants that represent the linear curve of the fuel consumption.

\subsection{Battery Energy Storage System Modeling}

The battery is an essential element in isolated microgrid systems. The battery capacity (kWh) can be expressed as [30]:

$$
C_{b a t}=\frac{E_{l} \times A D}{D O D \times \eta_{i n v} \times \eta_{b}}
$$

where $E_{l}$ represents the total energy load that should be transferred to the HRES; $A D$ represents the battery autonomy; $D O D$ is the depth of discharge (\%), which should avoid dominating the storage to the minimum state of the battery; and $\eta_{i n v}$ and $\eta_{b}$ are the efficiency of inverter and battery (\%), respectively, which consider the losses in the transfer of energy. 


\section{Mathematical Formulation of the Objective Function}

\subsection{Net Present Cost}

The objective preserved in this paper is to minimize the Net Present Cost (NPC), which represents the total investment project cost. It contains the sum of all systems capital $(C)$, operation and maintenance $(O M)$ and replacement $(R)$ costs, as well as the fuel cost of the diesel $\left(F C_{d g}\right)$ when it is added to the system. This paper also considers the interest rate $\left(i_{r}\right)$, inflation rate $(\delta)$, escalation rate $(\mu)$ and the project lifetime $(\mathrm{N})$. In summary, the NPC can be calculated as follows [31]:

$$
N P C=C+O M+R+F C_{d g}
$$

\subsubsection{Costs of PV and Wind}

The concept of cost calculation for PV and WT is generally similar. Their capital costs are based on the initial cost $\left(\lambda_{P V, W T}\right)$ and the area $\left(A_{P V, W T}\right)$. The capital cost of PV and/or wind is calculated as [32]:

$$
C_{P V, W T}=\lambda_{P V, W T} \times A_{P V, W T}
$$

The $O M$ costs are [32]:

$$
O M_{P V, W T}=\theta_{P V, W T} \times A_{P V, W T} \times \sum_{i=1}^{N}\left(\frac{1+\mu}{1+i_{r}}\right)^{i}
$$

where $\theta_{P V, W T}$ represents the annual operation and maintenance cost.

\subsubsection{Costs of Diesel Generation}

The diesel generator costs are calculated as [31]:

$$
\begin{gathered}
C_{d g}=\lambda_{d g} \times P_{d g} \\
O M_{d g}=\theta_{d g} \times N_{r u n} \times \sum_{i=1}^{N}\left(\frac{1+\mu}{1+i_{r}}\right)^{i} \\
R_{\text {diesel }}=R_{d g} \times P_{d g} \times \sum_{i=7,14 \ldots}\left(\frac{1+\delta}{1+i_{r}}\right)^{i} \\
C_{f}(t)=p_{f} \times F_{d g}<t> \\
F C_{d g}=\sum_{t=1}^{8760} C_{f}<t>\times \sum_{i=1}^{N}\left(\frac{1+\delta}{1+i_{r}}\right)^{i}
\end{gathered}
$$

where $C_{d g}$ is capital cost, $\lambda_{d g}$ represents initial cost of the diesel for each $\mathrm{KW}, O M_{d g}$ is the actual O\&M cost, $\theta_{d g}$ represents annual O\&M cost, $N_{r u n}$ represents operating hours number of diesel generator per year, $R_{\text {diesel }}$ is the diesel generator replacement cost, $R_{d g}$ is annual replacement cost, $p_{f}$ represents the fuel cost, $F_{d g}$ is annual fuel consumption and $F C_{d g}$ represents total fuel cost.

\subsubsection{Costs of Battery System}

The capital with OM (which contains the replacement) costs of battery are as follows [32]:

$$
\begin{gathered}
C_{B E S S}=\lambda_{b a t} \times C_{b a t} \\
O M_{B E S S}=\theta_{b a t} \times C_{b a t} \times \sum_{i=1}^{T_{B}}\left(\frac{1+\mu}{1+\delta}\right)^{\left(i_{i} 1\right) N_{b a t}}
\end{gathered}
$$

where $\lambda_{b a t}$ is the battery initial cost and $\theta_{b a t}$ represents battery annual O\&M cost. 


\subsubsection{Costs of Biomass System}

The biomass costs are calculated as [27]:

$$
\begin{gathered}
C_{b g}=\lambda_{b g} \times P_{b g} \\
O M_{b g}=\theta_{1} \times P_{b g} \times \sum_{i=1}^{N}\left(\frac{1+\mu}{1+i_{r}}\right)^{i}+\theta_{2} \times P_{w} \times \sum_{i=1}^{N}\left(\frac{1+\mu}{1+i_{r}}\right)^{i}
\end{gathered}
$$

where $\lambda_{b g}$ represents initial cost of biomass, $\theta_{1}$ is annual fixed O\&M cost, $\theta_{2}$ represents variable O\&M cost and $P_{w}$ is the annual generated energy ( $\mathrm{kWh} /$ Year).

\subsubsection{Costs of Inverter}

The capital and O\&M costs of the inverter are calculated as [31]:

$$
\begin{gathered}
C_{i n v}=\lambda_{i n v} \times P_{i n v} \\
O M_{\text {Inv }}=\theta_{I n v} \times \sum_{i=1}^{N}\left(\frac{1+\mu}{1+i_{r}}\right)^{i}
\end{gathered}
$$

where $\lambda_{i n v}$ is the inverter initial cost and $\theta_{I n v}$ is annual O\&M cost of inverter.

\subsection{Levelized Cost of Energy}

The Levelized Cost of Energy (LCOE) is calculated as follows [30]:

$$
L C O E=\frac{N P C \times C R F}{\sum_{t=1}^{8760} P_{\text {load }}<t>}
$$

where $P_{\text {load }}$ is the load demand and $C R F$ is the capital recovery factor that converts the initial to annual capital cost, which is calculated as follows:

$$
\operatorname{CRF}(i r, R)=\frac{i_{r} \times\left(1+i_{r}\right)^{R}}{\left(1+i_{r}\right)^{R}-1}
$$

where $R$ represents the lifetime of the project.

\subsection{Loss of Power Supply Probability}

The loss of power supply probability represents the reliability of microgrid system. LPSP is calculated as [30]:

$$
\text { LPSP }=\frac{\sum_{t=1}^{8760}\left(P_{\text {load }}<t>-P_{\text {pv }}<t>-P_{\text {wind }}<t>+P_{\text {dg,out }}<t>+P_{\text {SOC, bmin }}\right)}{\sum_{t=1}^{8760} P_{\text {load }}<t>}
$$

where $P_{S O C}$, bmin is the minimum state of charge of battery.

\subsection{Availability Index}

The availability index (A) is calculated to confirm the ability of the designed system as follows [32]:

$$
A=1-\frac{D M N}{\sum_{t=1}^{8760} P_{\text {load }}<t>}
$$

$$
D M N=P_{b \min }<t>-P_{b}<t>-\left(P_{p v}<t>+P_{\text {wind }}<t>+P_{\text {dg,out }}<t>-P_{\text {load }}<t>\right) \times u<t>
$$

where $P_{b}$ represent the battery power. $\mathrm{u}$ is equal to 1 if the load is not satisfied; otherwise, it is equal to 0 . 


\section{Optimization Algorithm}

The HMG design needs an efficient meta-heuristic algorithm that can help to resolve the system's complex operations. In a recent paper, we proposed a new optimization algorithm called Giza Pyramids construction. The effeteness of GPC is investigated through the hybrid microgrid design of two scenarios: PV/biomass and PV/wind/diesel/battery. Moreover, the GPC is compared with two other optimization algorithms to prove its ability to find the optimal solutions.

Harifi et al. [33] initially proposed the GPC algorithm, simulating the building process of the pyramids in Giza. The GPC optimization is a new population-based metaheuristic optimization algorithm that is inspired by the movement of workers and stone blocks during the pyramid building. The GPC is dedicated to several areas, including engineering applications.

To prove the effectiveness of the GPC, it is compared with two other algorithms, AEFA and GWO, which are presented in Appendices A.1 and A.2, respectively. Appendix A.3 represents the parameters of the algorithms declared above.

The GPC pseudocode is listed in Algorithm 1.

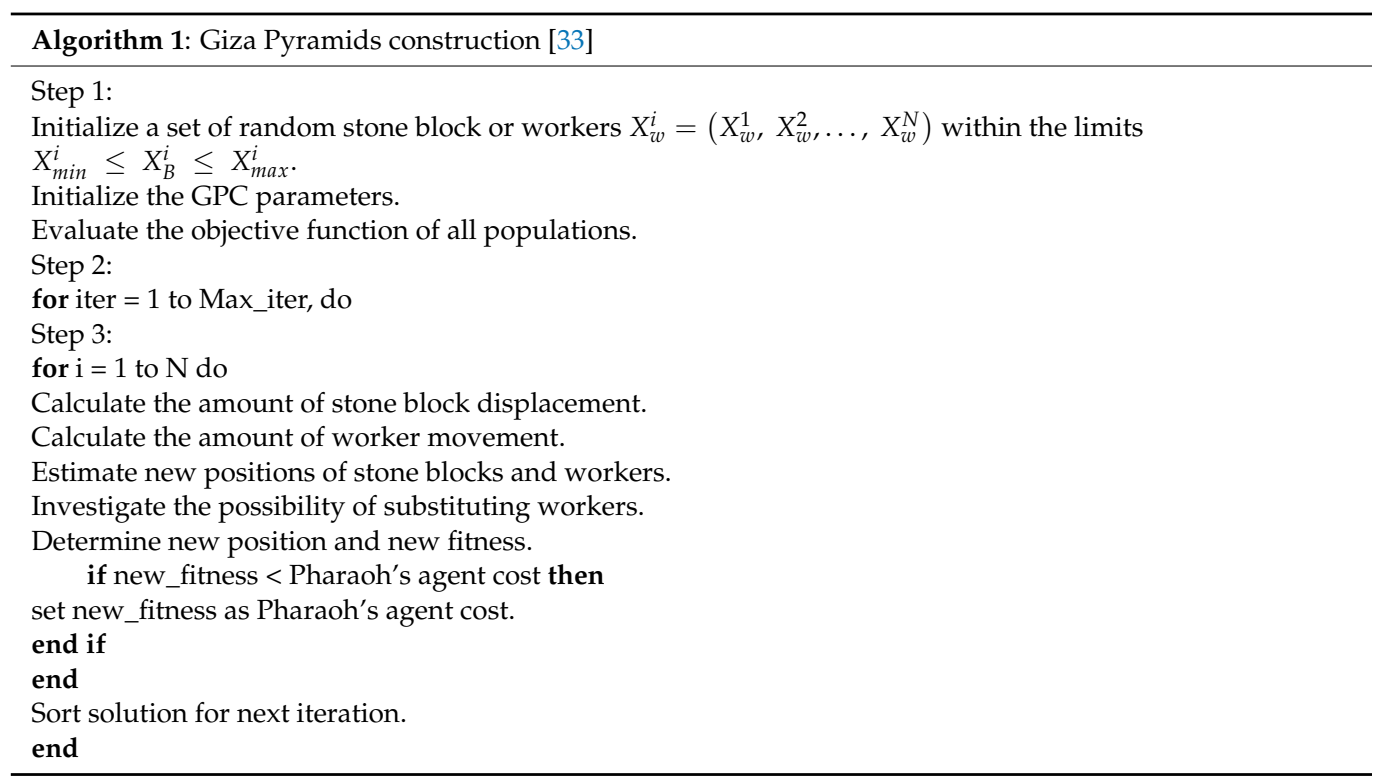

\section{Yanbu Case Study of the Hybrid Microgrid System}

The case study is proposed for the Yanbu region of Saudi Arabia, as shown Figure 5. The project is dedicated to feed a domestic load with the coordinate latitude $24.265^{\circ}$ and longitude $38.06^{\circ}$. A heat dump system is used to dump power.

The hourly load demand is presented in Figure 6 where the peak is about $43 \mathrm{~kW}$. The metrological data [34], including solar radiation, temperature, wind speed and pressure, are presented in Figures 7-10, respectively. The project economic and technical data are presented in Table 2 for PV, wind, biomass, diesel and battery systems. 


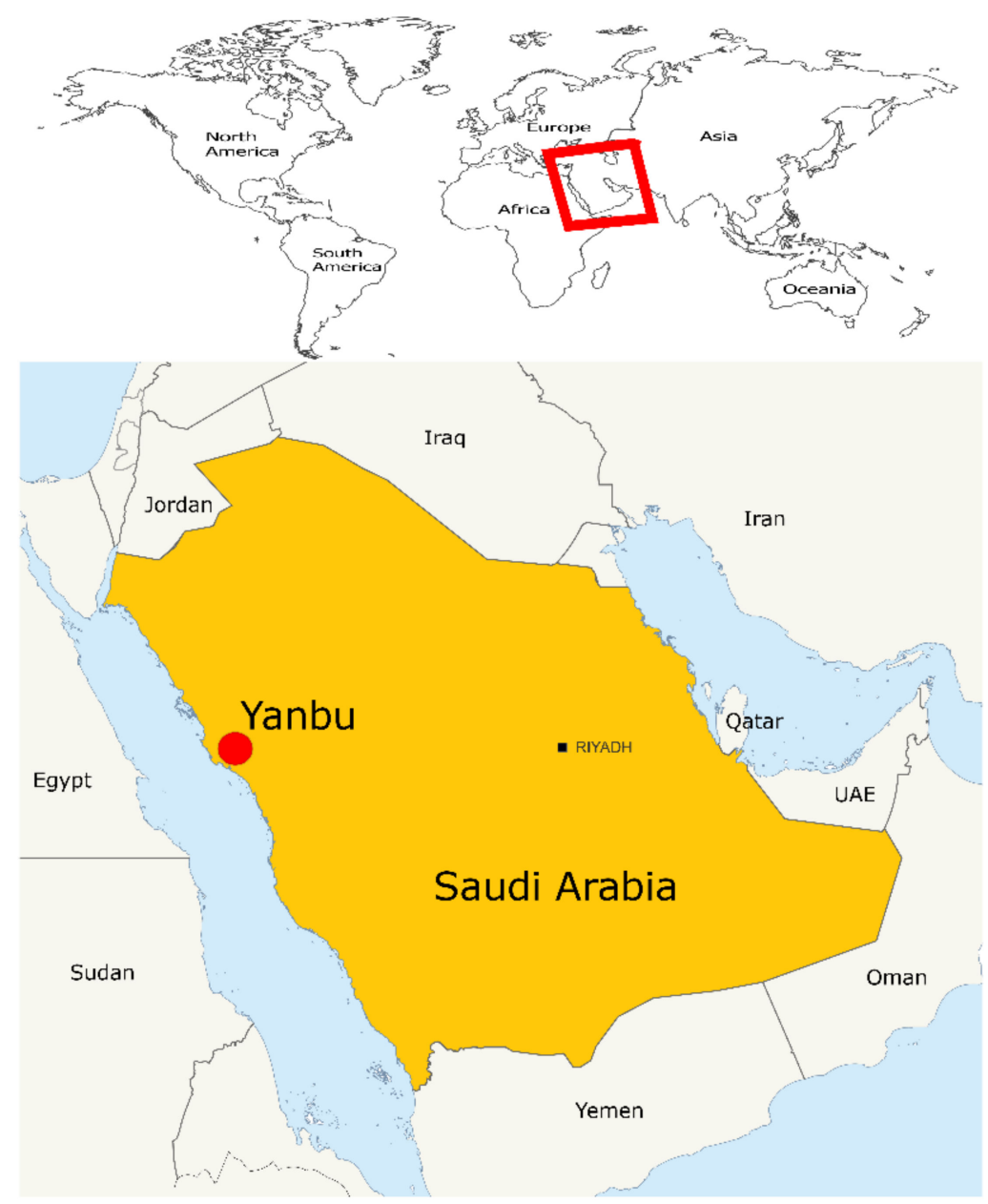

Figure 5. Map of Yanbu microgrid project.

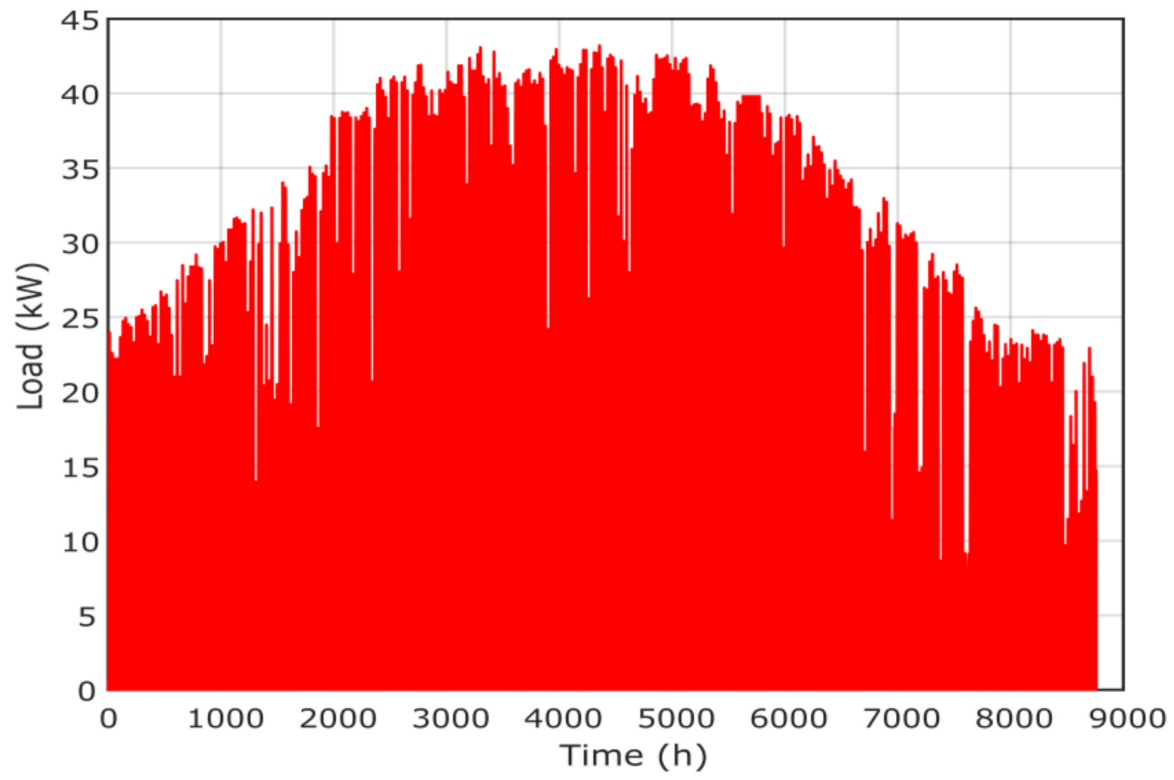

Figure 6. Annual power load of the project. 


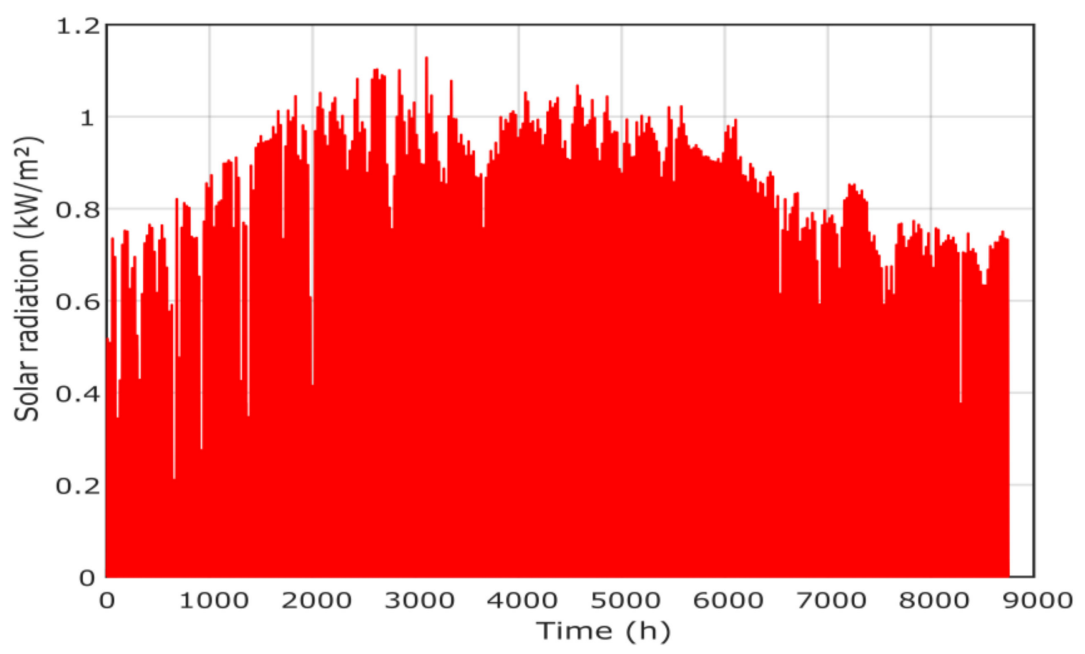

Figure 7. Solar radiation of the project location in Yanbu region.

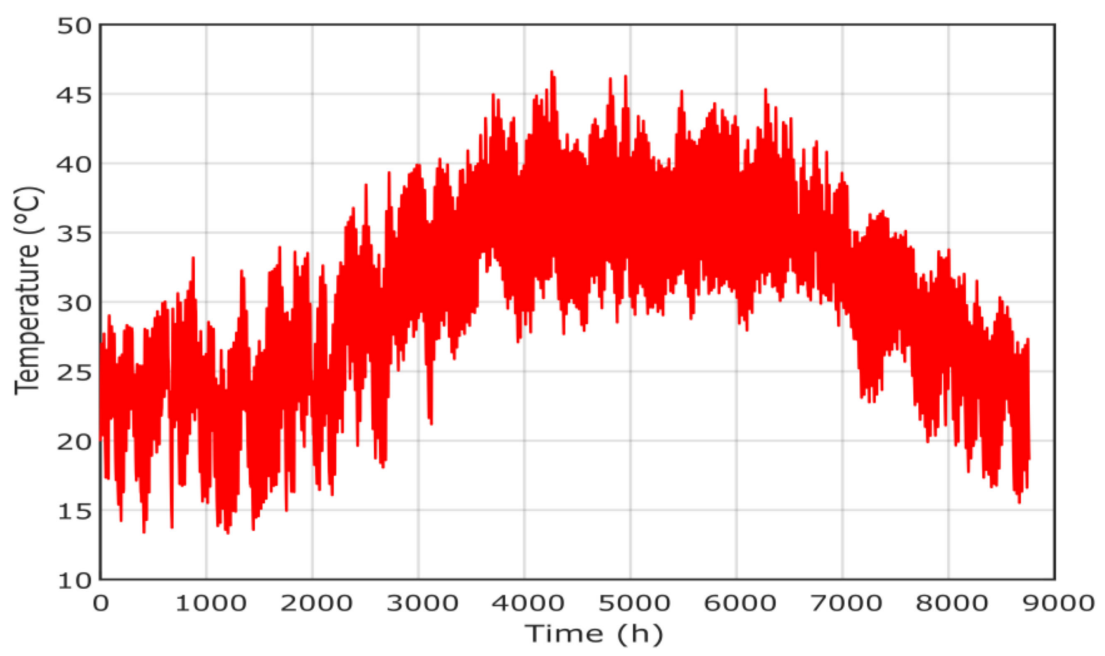

Figure 8. Temperature of the project location in Yanbu region.

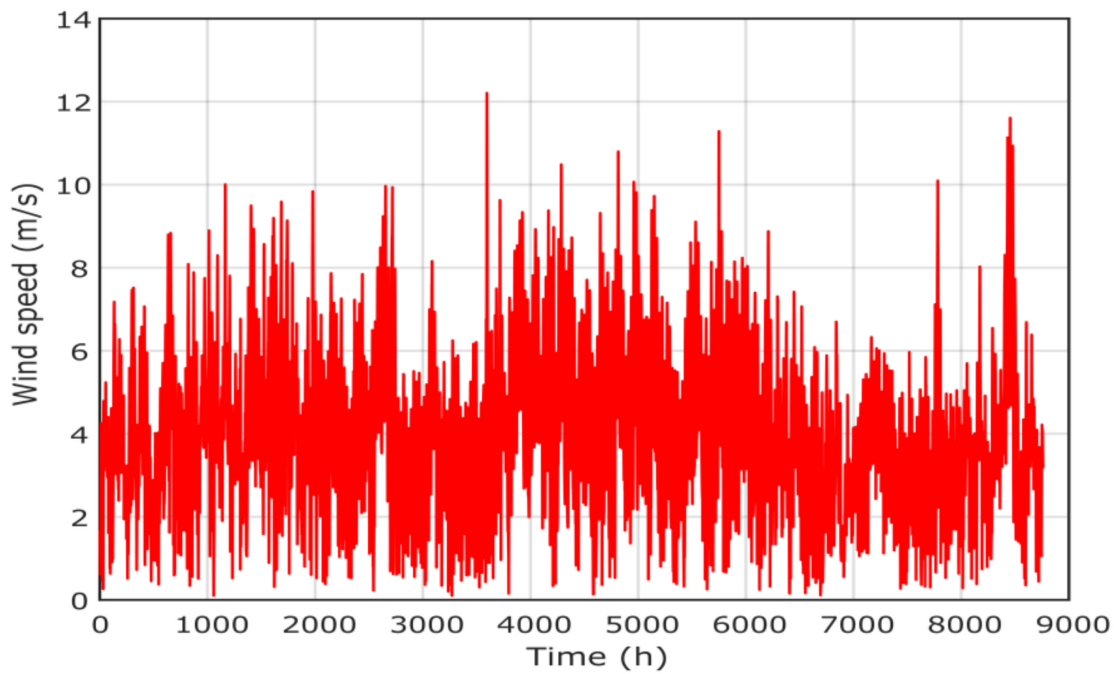

Figure 9. Wind speed of project location in Yanbu region. 


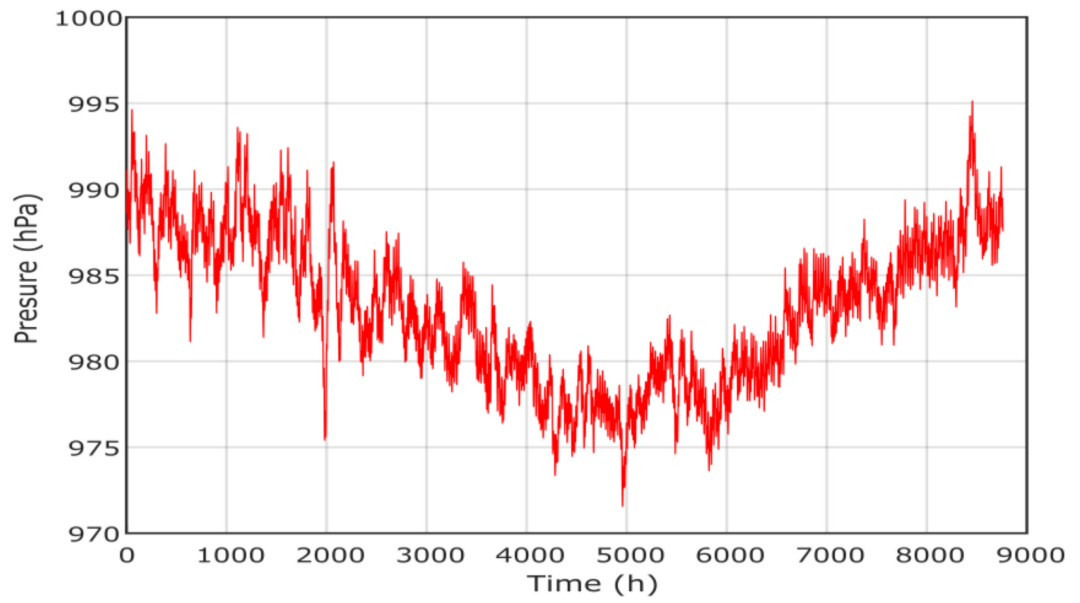

Figure 10. Annual pressure of project in Yanbu region.

Table 2. The project data: economic and technical [27,30-32].

\begin{tabular}{|c|c|c|}
\hline Symbol & Indix & Quantity \\
\hline$N$ & Microgrid project lifetime & 20 years \\
\hline$i_{r}$ & Interest rate index & $0.882 \%$ \\
\hline$\mu$ & Escalation rate index & $5 \%$ \\
\hline$\delta$ & Inflation rate index & $2 \%$ \\
\hline \multicolumn{3}{|l|}{ PV system } \\
\hline$\lambda_{p v}$ & initial cost of PV & $\$ 400 / \mathrm{m}^{2}$ \\
\hline$\theta_{p v}$ & Annual cost of PV O\&M & $\$ 0.01 \times \lambda_{p v} / \mathrm{m}^{2} /$ year \\
\hline$\eta_{r}$ & Reference efficiency of PV & $25 \%$ \\
\hline$\eta_{t}$ & MPPT Efficiency & $100 \%$ \\
\hline$T_{r}$ & $\begin{array}{l}\text { reference temperature of cell } \\
\text { PV }\end{array}$ & $25^{\circ} \mathrm{C}$ \\
\hline$\beta$ & Temperature coefficient & $0.005^{\circ} \mathrm{C}$ \\
\hline NOCT & $\begin{array}{l}\text { Nominal operating } \\
\text { temperature cell }\end{array}$ & $47^{\circ} \mathrm{C}$ \\
\hline$N_{p v}$ & PV system lifetime & 20 years \\
\hline \multicolumn{3}{|l|}{ WT system } \\
\hline$\lambda_{\text {wind }}$ & Wind initial cost & $\$ 125 / \mathrm{m}^{2}$ \\
\hline$\theta_{\text {wind }}$ & Annual O\&M cost of wind & $\$ 0.01 \times \lambda_{\text {wind }} / \mathrm{m}^{2} /$ year \\
\hline$C_{p_{-} \text {wind }}$ & Maximum power coefficient & $48 \%$ \\
\hline$V_{c i}$ & Cut-in wind speed & $2.6 \mathrm{~m} / \mathrm{s}$ \\
\hline$V_{c o}$ & Cut-out wind speed & $25 \mathrm{~m} / \mathrm{s}$ \\
\hline$V_{r}$ & Rated wind speed & $9.5 \mathrm{~m} / \mathrm{s}$ \\
\hline$N_{\text {wind }}$ & Wind system lifetime & 20 years \\
\hline \multicolumn{3}{|l|}{ Diesel generator } \\
\hline$\lambda_{d g}$ & Diesel initial cost & $\$ 250 / \mathrm{kW}$ \\
\hline$\theta_{d g}$ & Annual O\&M cost of diesel & $\$ 0.05 / \mathrm{h}$ \\
\hline$R_{d g}$ & Replacement cost & $\$ 210 / \mathrm{kW}$ \\
\hline$p_{f}$ & Fuel price in Egypt & $\$ 0.43 / \mathrm{L}$ \\
\hline$N_{\text {diesel }}$ & Diesel system lifetime & 7 years \\
\hline \multicolumn{3}{|l|}{ BESS } \\
\hline$\lambda_{b a t}$ & Initial cost of battery & $\$ 100 / \mathrm{kWh}$ \\
\hline$\theta_{b a t}$ & $\begin{array}{l}\text { Annual O\&M cost of the } \\
\text { battery }\end{array}$ & $\$ 0.03 \times \lambda_{\text {bat }} / \mathrm{m}^{2} /$ year \\
\hline$D O D$ & Depth of discharge & $80 \%$ \\
\hline$\eta_{b}$ & Battery efficiency & $97 \%$ \\
\hline$S O C_{\min }$ & Minimum state of charge & $20 \%$ \\
\hline$S O C_{\max }$ & Maximum state of charge & $80 \%$ \\
\hline$N_{b a t}$ & Battery system lifetime & 5 years \\
\hline
\end{tabular}


Table 2. Cont.

\begin{tabular}{lll}
\hline \multicolumn{1}{c}{ Symbol } & \multicolumn{1}{c}{ Indix } & \multicolumn{1}{c}{ Quantity } \\
\hline Inverter & & \\
$\lambda_{\text {inv }}$ & Inverter initial cost & $\$ 400 / \mathrm{kW}$ \\
$\theta_{\text {inv }}$ & Annual O\&M cost of inverter & $\$ 20 /$ year \\
$\eta_{\text {inv }}$ & Inverter efficiency & $97 \%$ \\
\hline
\end{tabular}

\section{Results and Discussions}

In this paper, GPC is chosen and implemented to design an HMG system. PV, wind turbine, biomass system, diesel generator and battery storage system are used for two scenarios:
(A) PV/biomass hybrid microgrid system
(B) $\mathrm{PV} /$ wind/diesel/battery microgrid system

The results obtained by GPC are compared with those of the AEFA and GWO algorithms to validate its ability and effectiveness in achieving the best optimal design with high reliability and minimum investment costs. The simulations were performed using MATLAB editor R2018a. The convergence of the three optimization algorithms (GPC, AEFA and GWO) are shown in Figures 11-13, which display the convergence curves of all algorithms. It is clear that the GPC algorithm achieves the best optimal designs for both configurations. Figure 11 presents the $\mathrm{PV} /$ biomass system convergence curves, which show that the GPC has the best results compared to those of the AEFA and GWO algorithms. Figure 12 presents the convergence curve of PV/diesel/battery system, using GPC, AEFA and GWO. Figure 13 presents the convergence of PV/wind/diesel/battery system, proving that GPC is the best algorithm. Thus, GPC needs less computational time to find the optimal system, which reduces the computer source usage, as well as reduces the system cost. The AEFA and GWO algorithms need more time for convergence. The best value of convergence is found in Iterations 59 (GPC), 87 (AEFA) and 75 (GWO) for the first $\mathrm{PV} /$ biomass microgrid system. For the second system, the best value is found at Iterations 54(GPC), 88 (AEFA) and 47 (GWO). For the third configuration, the optimal is found at Iterations 53 (GPC), 55 (AEFA) and 12 (GWO). Typically, in microgrid design problems, 100 iterations are sufficient.

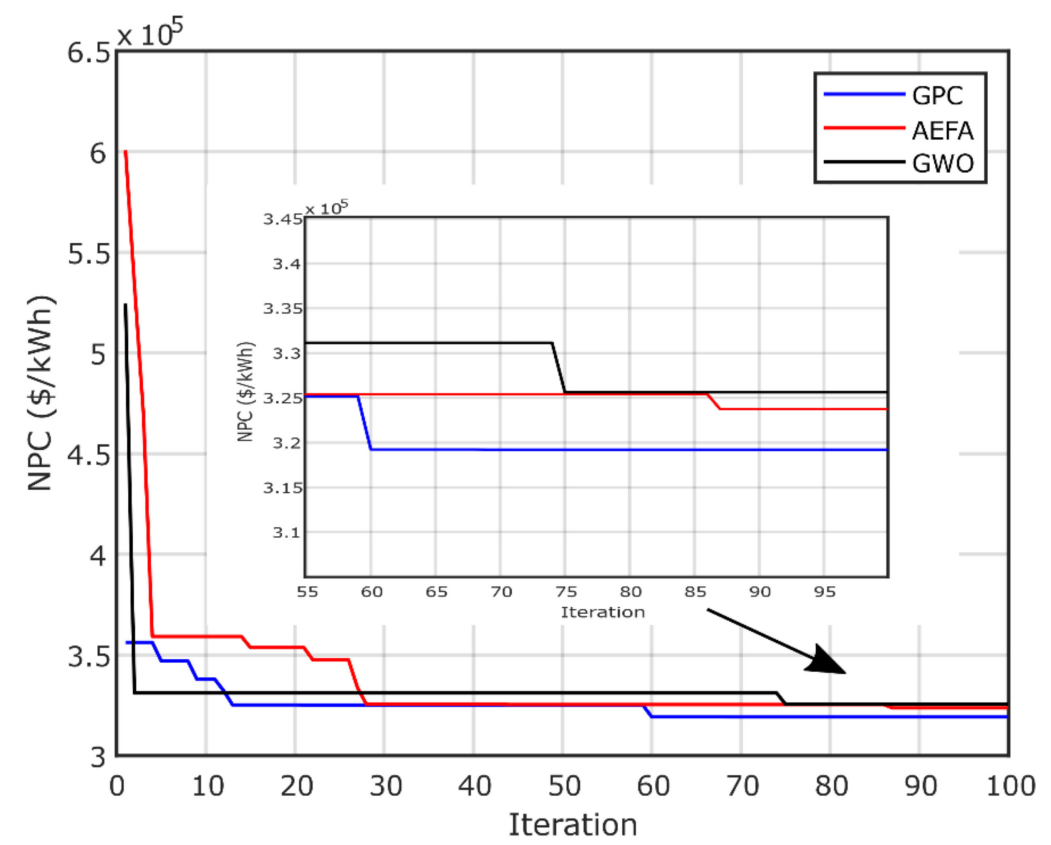

Figure 11. NPC convergence of PV/biomass system. 


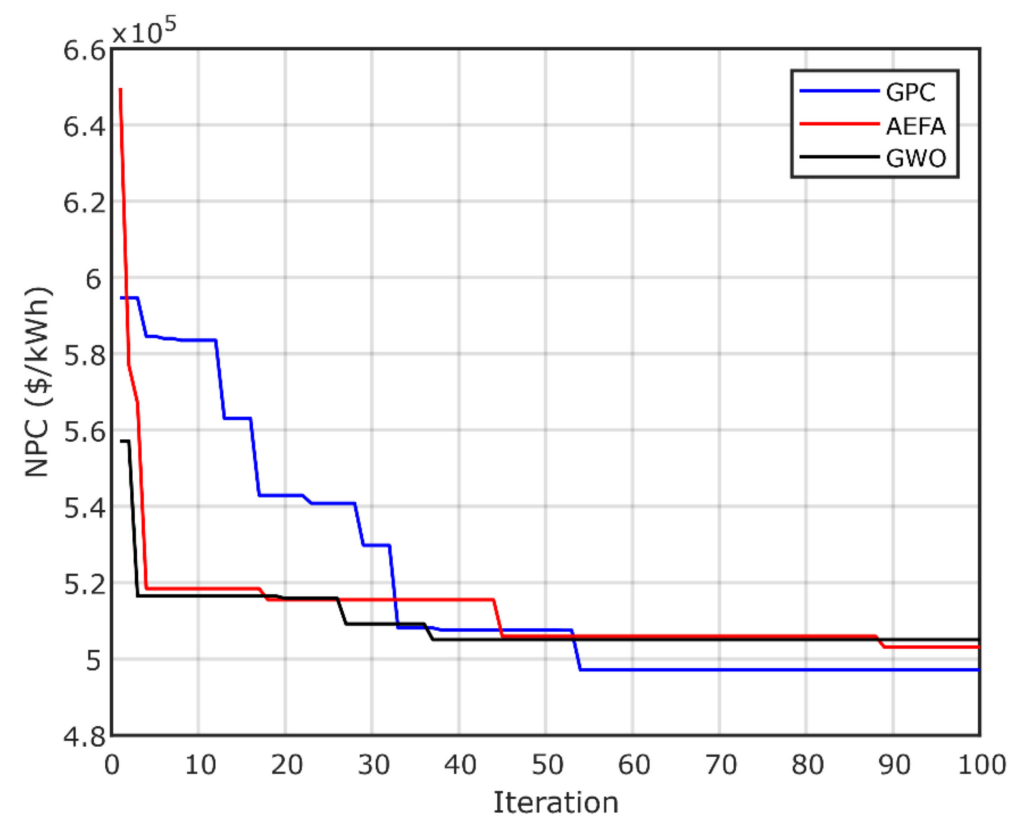

Figure 12. NPC convergence of PV/diesel/battery system.

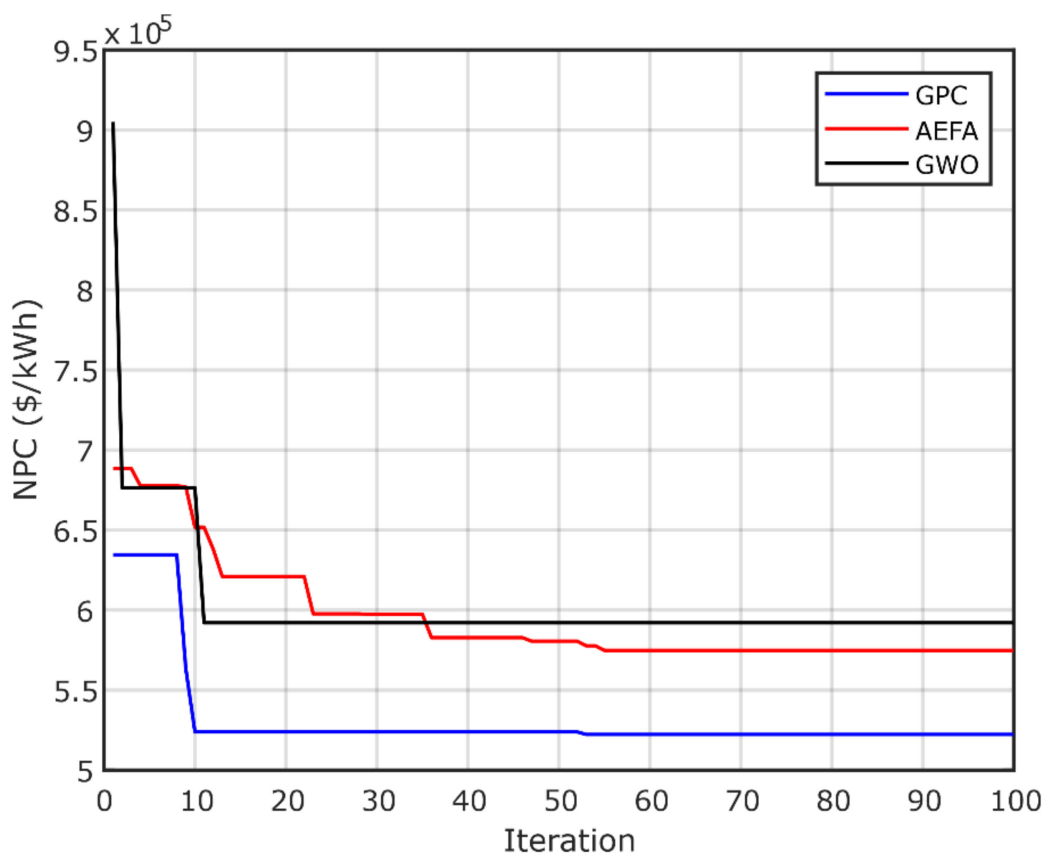

Figure 13. NPC convergence of PV/wind/diesel/battery system.

The objective functions (NPC) and other technical and economical calculated parameters for both hybrid microgrid systems are listed in Table 3. From the obtained results, the best optimal microgrid design in this study is found for the first scenario of PV / biomass system with NPC of $\$ 319,219$ and LCOE of $\$ 0.208 / \mathrm{kWh}$ for cost of energy. The associated LPSP limit is 0.049 and the availability is about $96 \%$. The optimal results are obtained using the GPC algorithm in both configurations, where the computational time of GPC is the shortest compared with those of AEFA and GWO as shown in Table 4. This project's optimal microgrid system is to install $265,870 \mathrm{~m}^{2}$ of PV panel with a 1000 ton/year biomass generator. 
Table 3. Economic and technical factor results for all configurations.

\begin{tabular}{|c|c|c|c|c|c|c|}
\hline Microgrid System & Algorithm & NPC (\$) & LCOE (\$/kWh) & LPSP (\%) & A ( $\%)$ & AD (Day) \\
\hline \multirow{3}{*}{ PV/biomass } & GPC & 319,219 & 0.208 & 0.049 & 96.409 & - \\
\hline & AEFA & 323,724 & 0.211 & 0.046 & 96.450 & - \\
\hline & GWO & 325,612 & 0.213 & 0.048 & 96.527 & - \\
\hline \multirow{3}{*}{ PV/diesel/BESS } & GPC & 497,124 & 0.325 & 0.045 & 99.825 & 0.9 \\
\hline & AEFA & 503,112 & 0.328 & 0.041 & 99.736 & 2.2 \\
\hline & GWO & 505,078 & 0.329 & 0.039 & 99.858 & 0.7 \\
\hline \multirow{3}{*}{ PV/WT/diesel/BESS } & GPC & 522,290 & 0.341 & 0.05 & 95 & 0 \\
\hline & AEFA & 574,806 & 0.375 & 0.045 & 98.826 & 2 \\
\hline & GWO & 592,074 & 0.386 & 0.046 & 98.705 & 2.09 \\
\hline
\end{tabular}

Table 4. Design results of PV/biomass and PV/wind/diesel/battery systems using GPC, AEFA and GWO optimization methods.

\begin{tabular}{|c|c|c|c|c|c|c|c|}
\hline Microgrid System & Algorithm & $\operatorname{PV}\left(\mathrm{m}^{2}\right)$ & Wind $\left(\mathrm{m}^{2}\right)$ & Diesel (kW) & Battery (kWh) & Biomass (Ton/Year) & Time(s) \\
\hline \multirow{3}{*}{ PV/biomass } & GPC & 265.870 & - & - & - & 1000 & 46,291 \\
\hline & AEFA & 295.263 & - & - & - & 995.954 & 82,420 \\
\hline & GWO & 305.290 & - & - & - & 981.023 & 161,439 \\
\hline \multirow{3}{*}{ PV/diesel/BESS } & GPC & 372.168 & - & 25.199 & 11.195 & - & 229,861 \\
\hline & AEFA & 360.071 & - & 25.969 & 28.247 & - & 50,794 \\
\hline & GWO & 390.121 & - & 25.279 & 8.866 & - & 87,471 \\
\hline \multirow{3}{*}{ PV/WT/diesel/BESS } & GPC & 535 & 2000 & 0 & 0 & - & 53,392 \\
\hline & AEFA & 191 & 1837 & 34 & 26 & - & 338,099 \\
\hline & GWO & 284 & 1741 & 31 & 26 & - & 592,074 \\
\hline
\end{tabular}

Figure 14 presents the annual contribution of the optimal microgrid system using the proposed GPC algorithm, while Figure 15 presents the time response of PV and biomass. Figures 16 and 17 present the annual contribution and the time response of $\mathrm{PV} /$ diesel/battery. Figure 18 presents the annual contribution of PV/wind/diesel/battery using the GPC algorithm, while Figure 19 presents the time response of the PV and wind systems.

Figure 20 shows the required costs of $\mathrm{PV}$, biomass and inverter, considering the capital, operation/maintenance, replacement and resale costs. All costs are expressed in dollars. Figures 21 and 22 show the detailed costs of the two studied configurations, $\mathrm{PV} /$ diesel/battery and PV/wind/diesel/battery, respectively, where PV is the least expensive in both configurations. The cost of fuel is the highest during the project lifetime at $\$ 287,549$ in the second configuration. Figure 23 presents the percent of total annual contribution, of which PV is the first contributor with $85 \%$; similarly, PV represents $71.73 \%$ in the second configuration. The wind is the most important contributor in the PV/wind/diesel/battery with 59.75\%. 


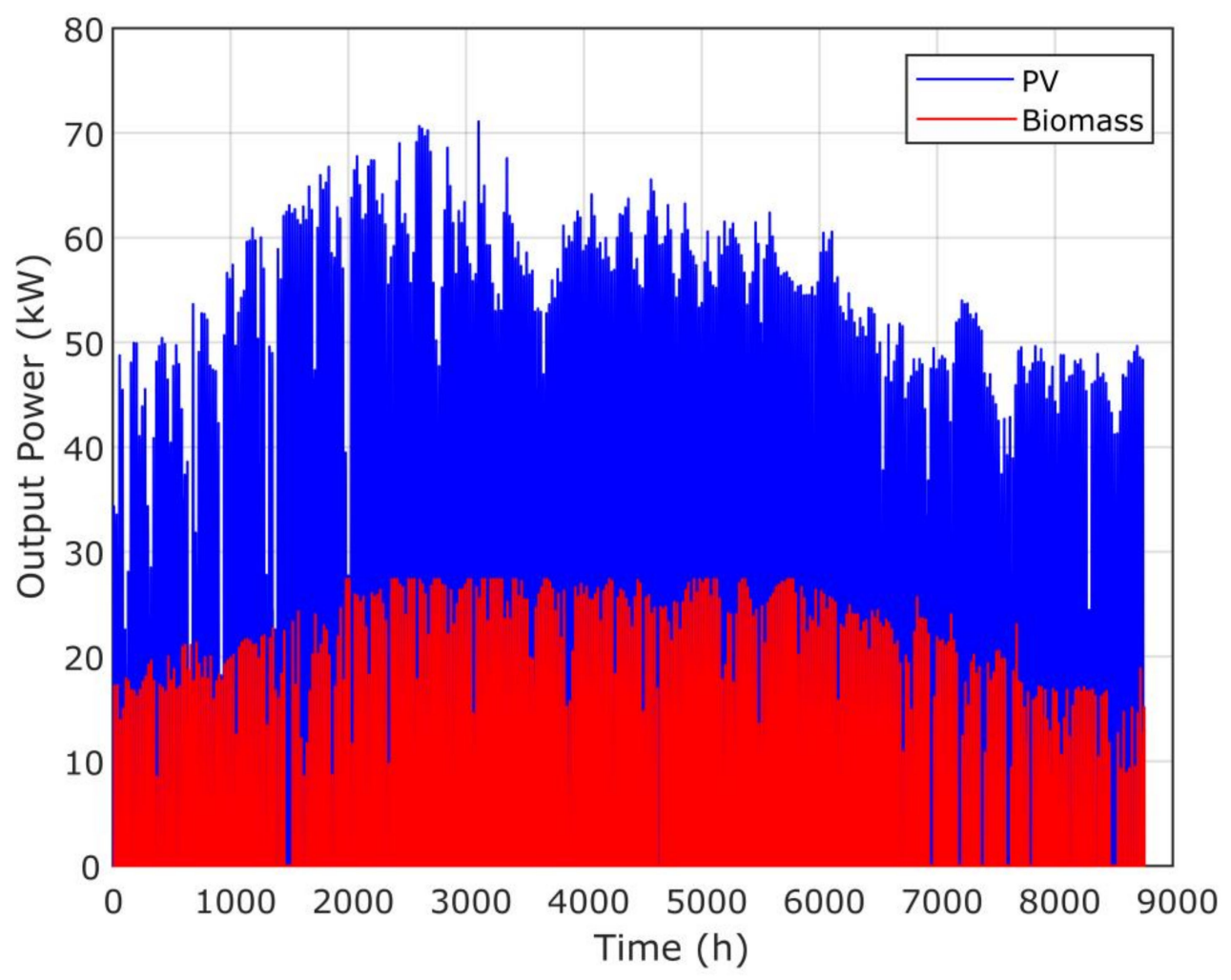

Figure 14. Annual contribution of PV/biomass system using the GPC algorithm.

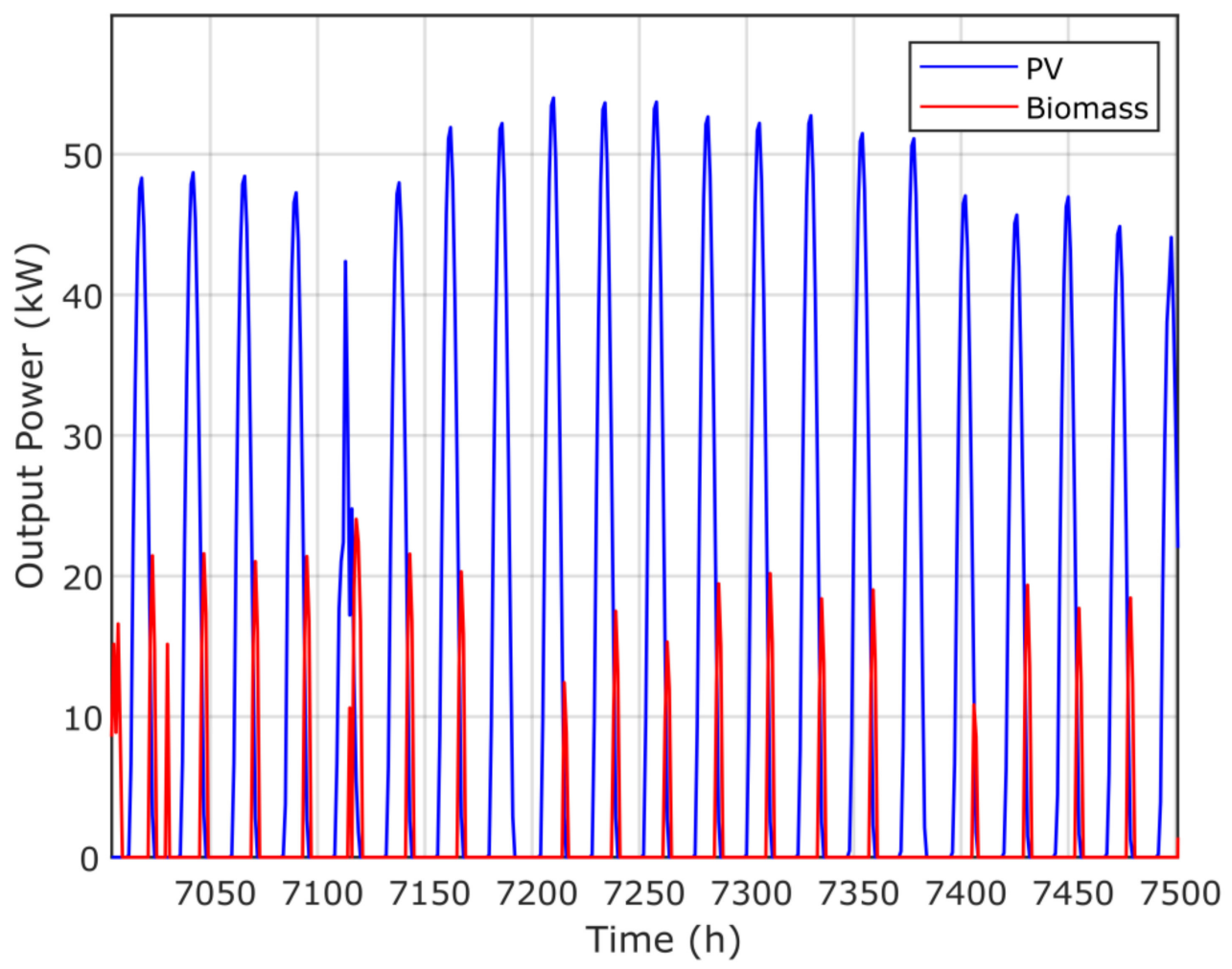

Figure 15. Time-response of the PV and biomass system via the GPC algorithm. 


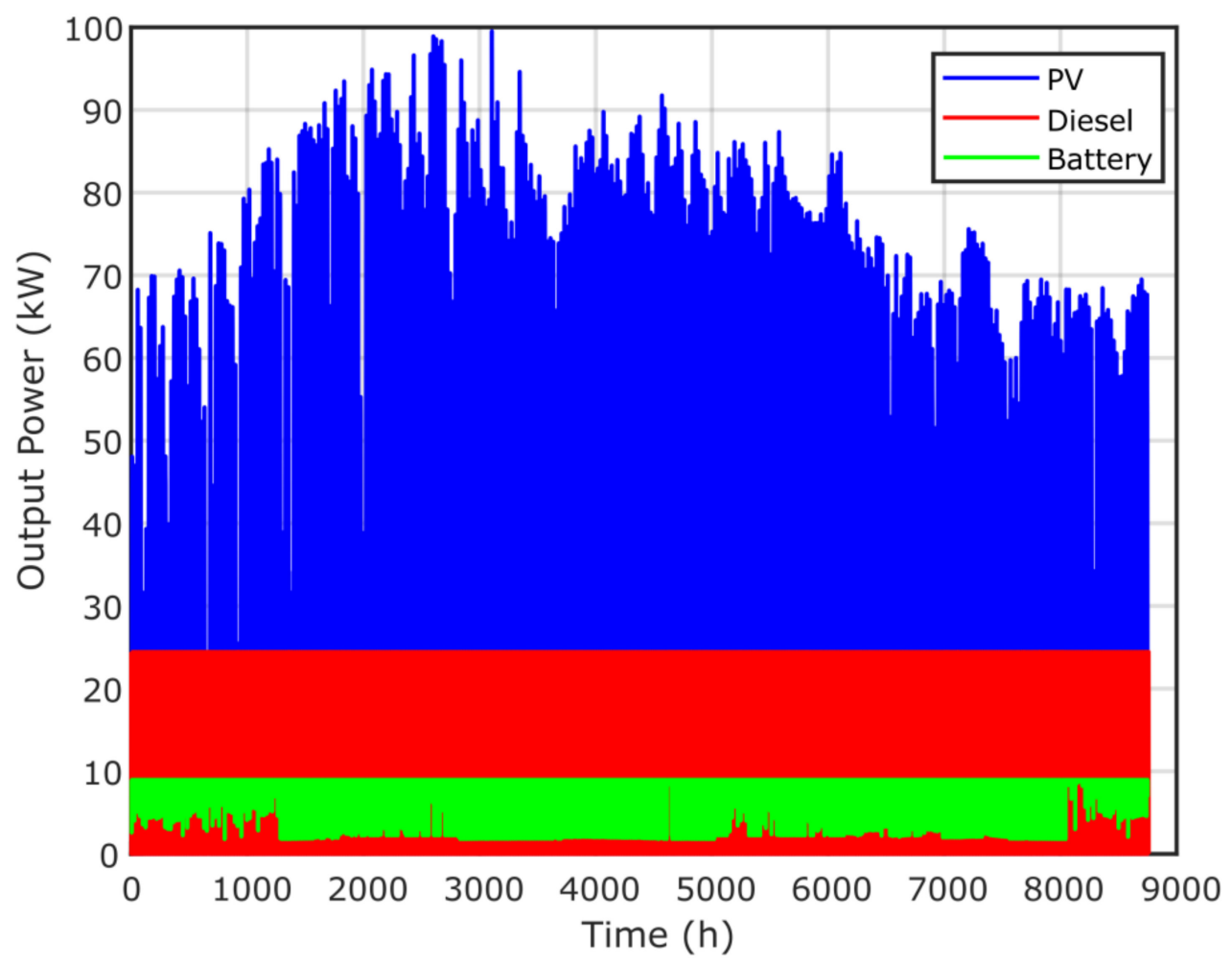

Figure 16. Annual contribution of PV/diesel/battery system using the GPC algorithm.

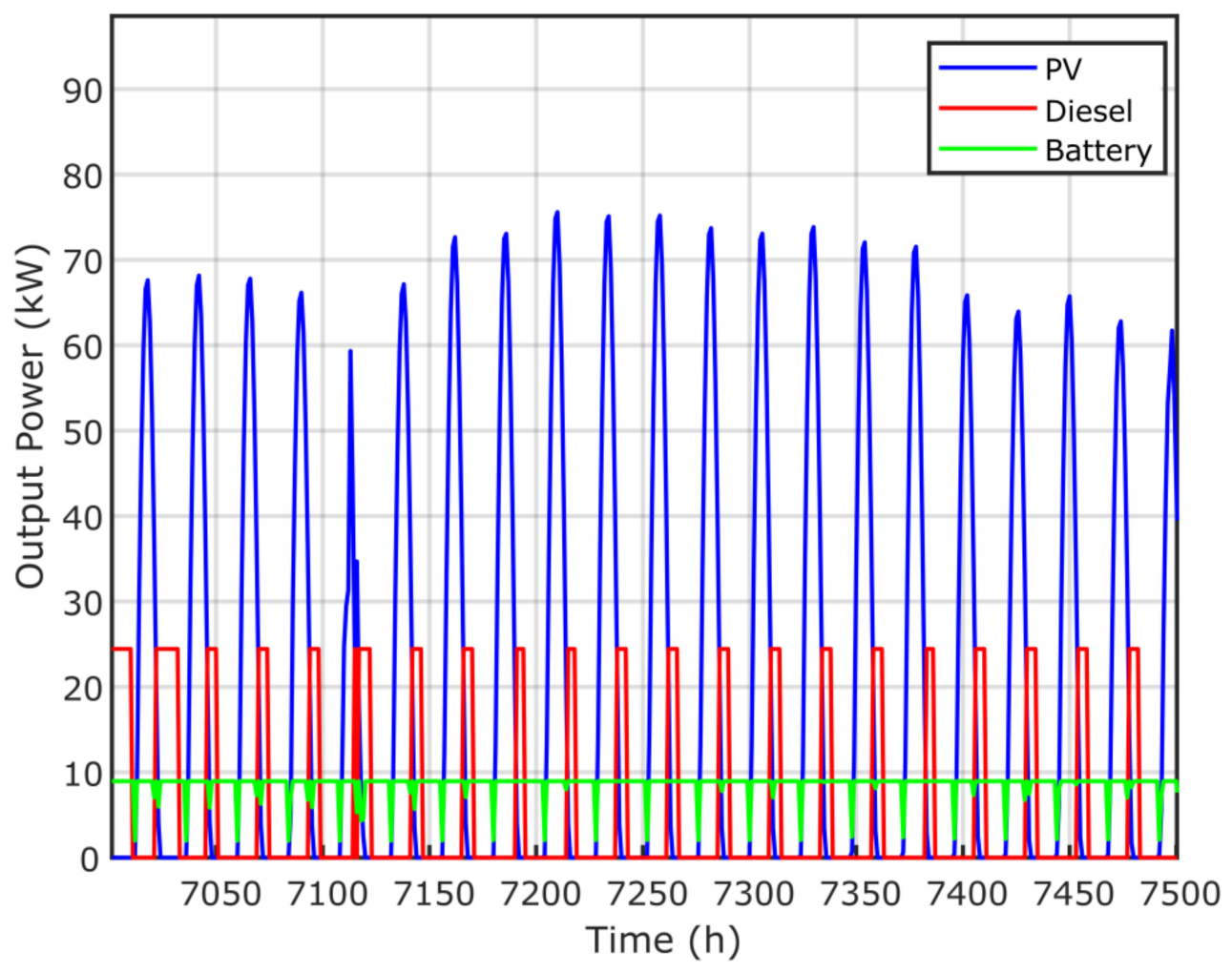

Figure 17. Time-response of the PV, diesel and battery generator via the GPC algorithm. 


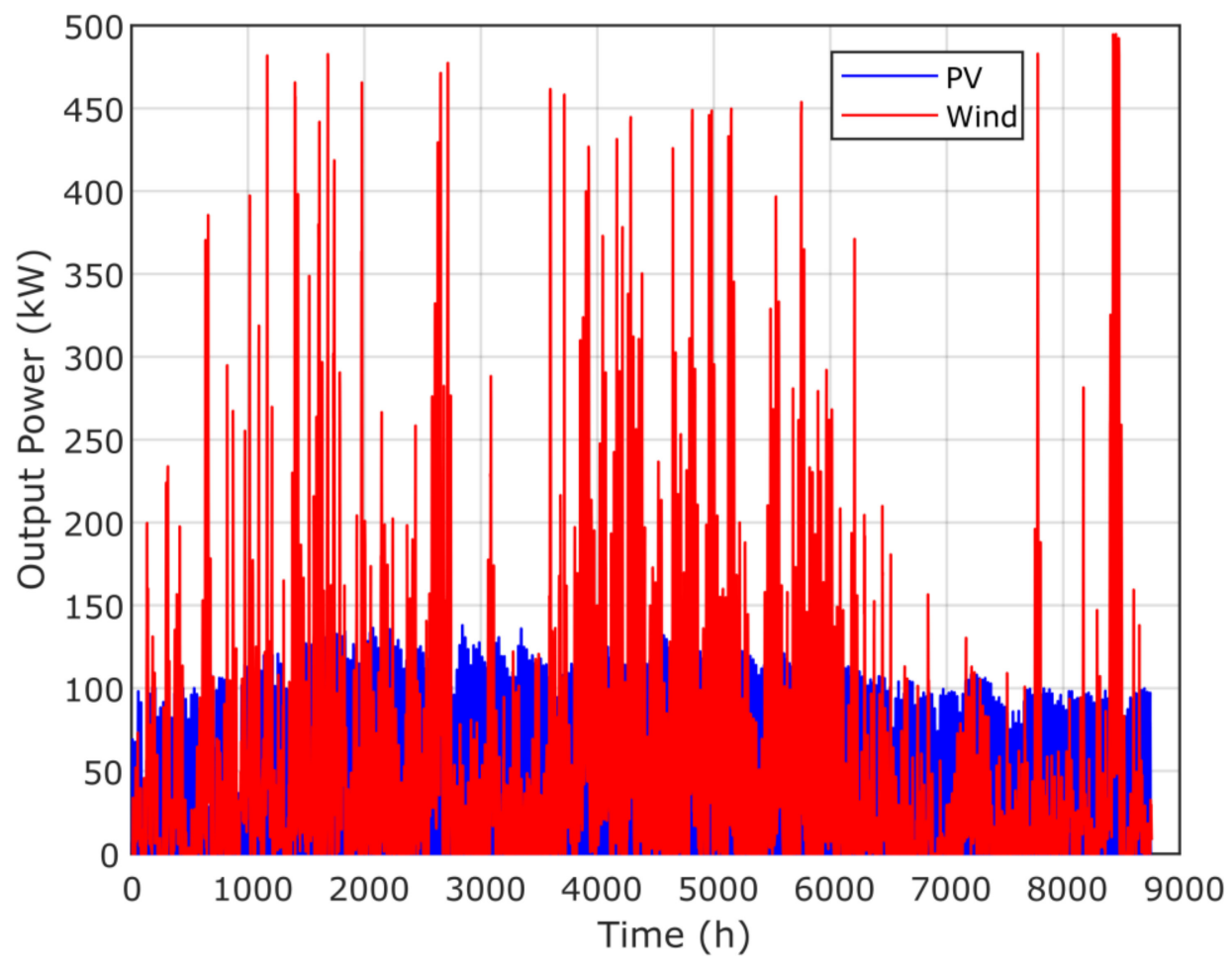

Figure 18. Annual contribution of PV/wind/diesel/battery using the GPC algorithm.

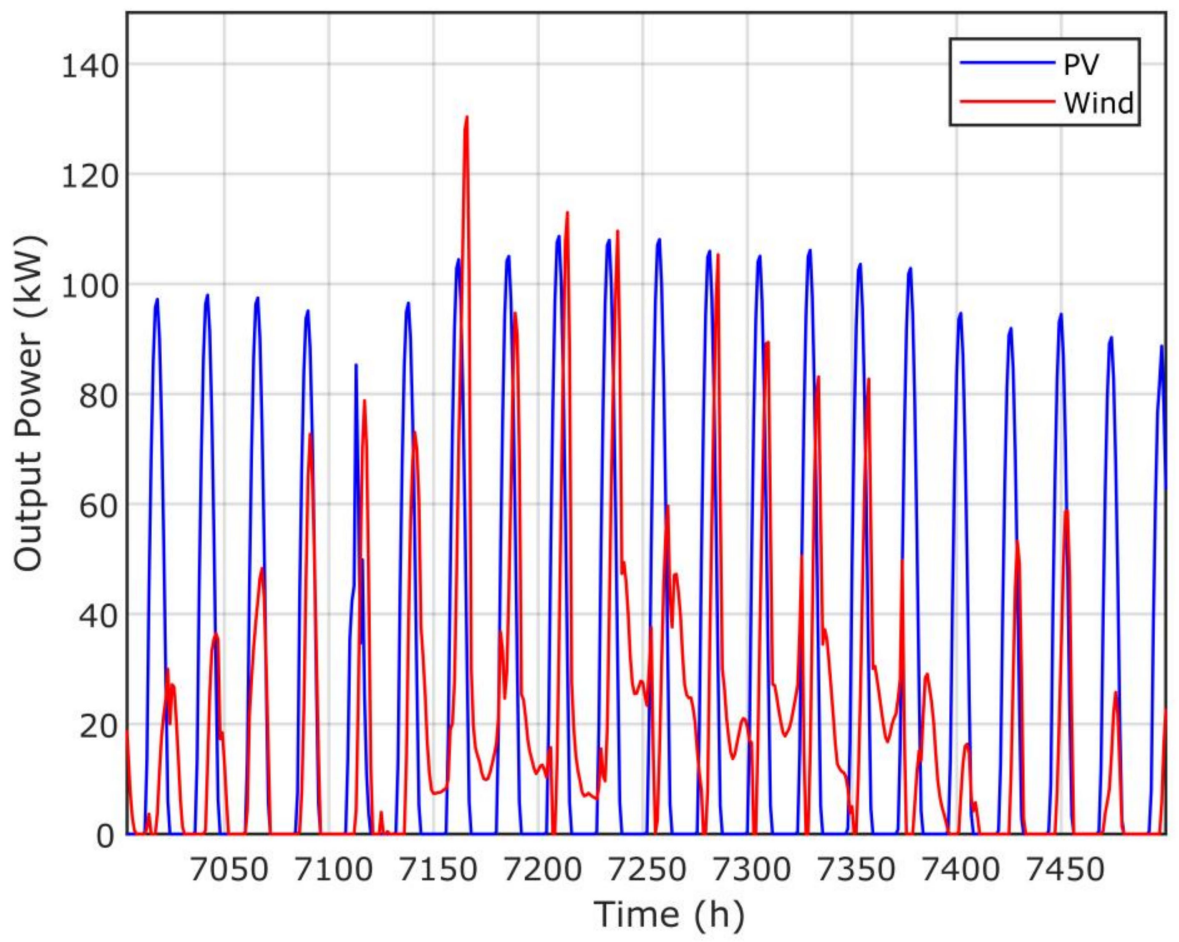

Figure 19. Time-response of PV and wind via the GPC algorithm. 


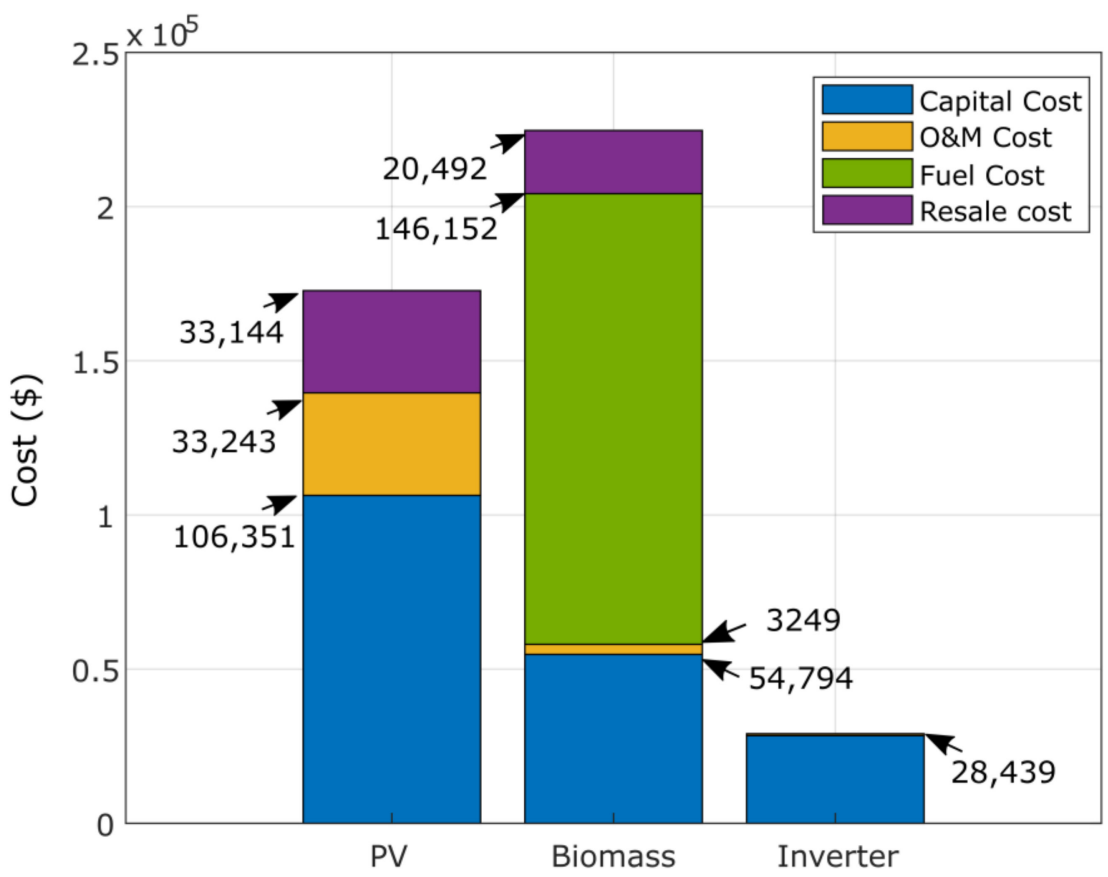

Figure 20. Detailed cost results (\$) of the optimal PV/biomass system obtained using GPC algorithm.

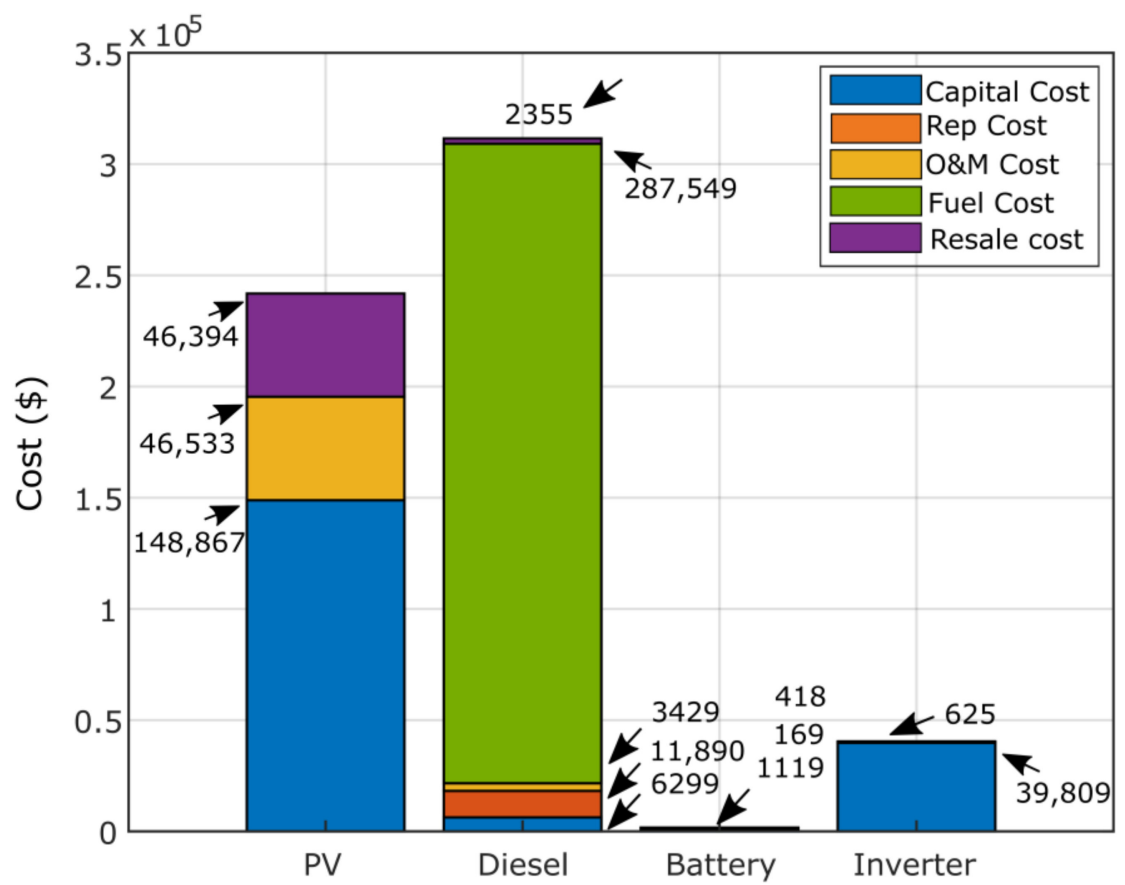

Figure 21. Detailed cost results (\$) of the optimal PV/diesel/battery system obtained using GPC algorithm. 


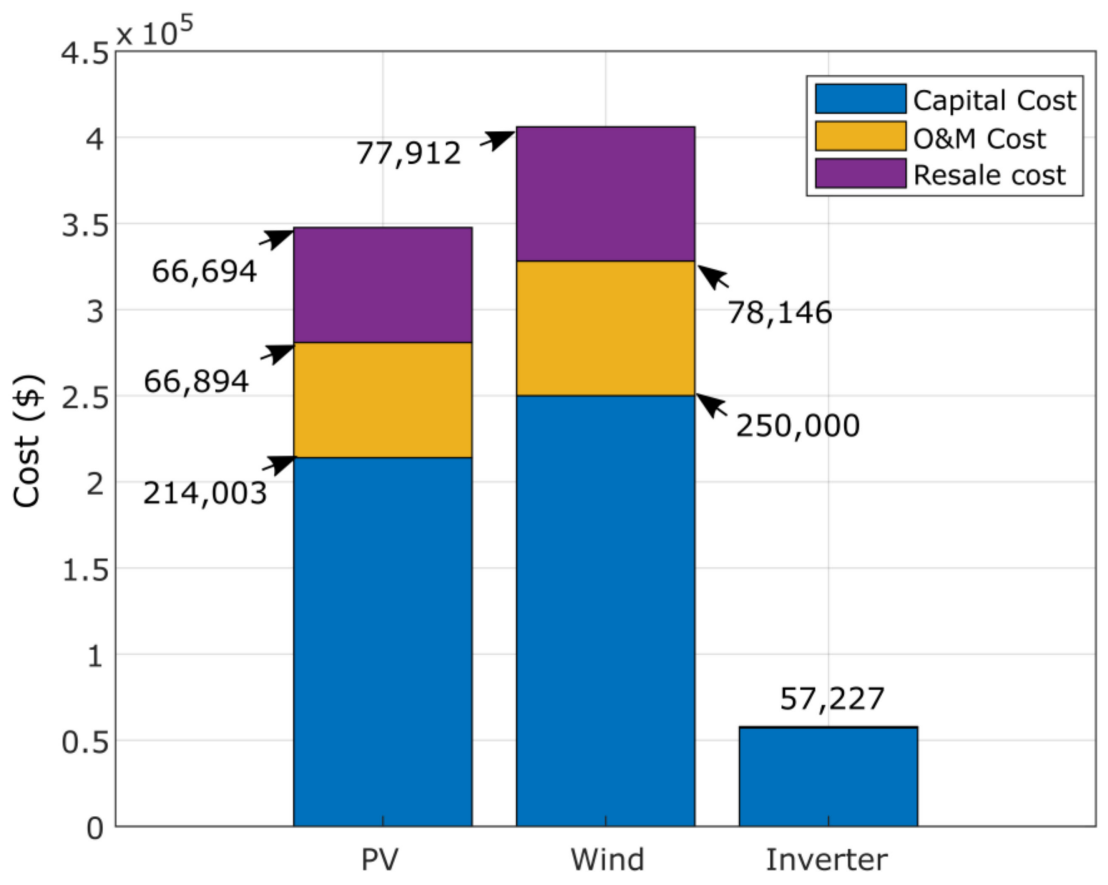

Figure 22. Detailed costs results (\$) of the optimal PV/wind/diesel/battery system obtained using GPC algorithm.

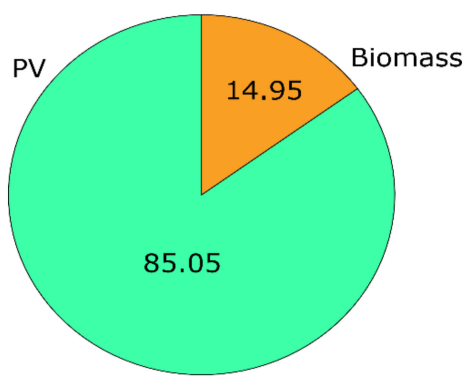

(a) PV/biomass

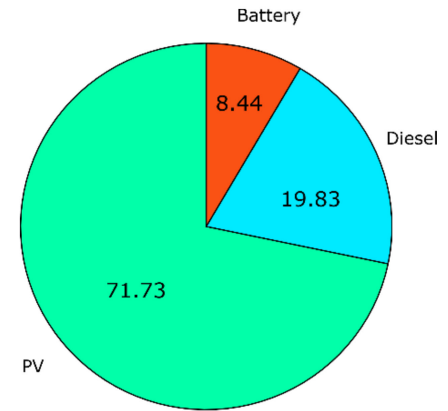

(b) PV/diesel/battery

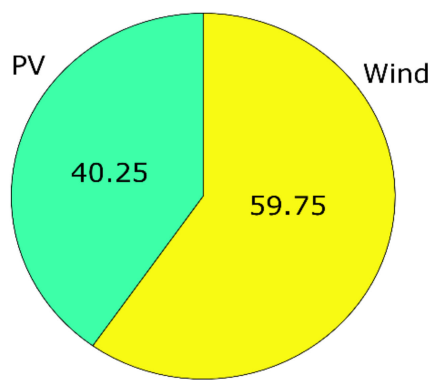

(c) $\mathrm{PV} /$ wind/diesel/battery.

Figure 23. Power contribution percent of microgrid systems using the GPC algorithm: (a) PV/biomass; (b) PV/diesel/battery; and (c) PV/wind/diesel/battery.

\section{Conclusions}

The hybrid microgrid isolated systems is a cost-effective system, especially in Saudi Arabia, where solar radiation is significant. The paper presents the design of three hybrid microgrid systems in Yanbu region. The minimum cost of investment is obtained using the $\mathrm{PV} /$ biomass system by applying the recent GPC optimization algorithm. The developed algorithm is compared with the AEFA and GWO algorithms. The objective function is to minimize the net present cost respecting some technical constraints. The best optimal 
system has $265,870 \mathrm{~m}^{2}$ of PV and 1000 ton/year biomass generator. The NPC is $\$ 319,219$ and LCOE is $\$ 0.208 / \mathrm{kWh}$. In future work, the proposal and implementation of new optimization algorithms and new microgrid system configurations will be the main focus. A new framework containing an efficient algorithm and a good power management helps to find a cost-effective microgrid system.

Author Contributions: Conceptualization, M.K., S.K. and A.S.A.; Data curation, M.I.M., A.E. and M.A.; Formal analysis, M.A. and M.A.-A.; Resources, A.E., M.A.-A. and M.I.M.; Methodology, M.A., A.S.A. and M.A.; Software, M.K., and S.K.; Supervision, M.A.; Validation, M.K. and S.K.; Visualization, M.A., M.A.-A. and A.S.A.; Writing—original draft, M.K., M.A.-A. and M.I.M.; Writing-review and editing, M.A., A.E. and M.I.M. All authors together organized and refined the manuscript in the present form. All authors have approved the final version of the submitted paper. All authors have read and agreed to the published version of the manuscript.

Funding: This research was funded by the deputyship for Research \& Innovation Ministry of Education in Saudi Arabia grant number IFP-2020-06.

Institutional Review Board Statement: Not applicable.

Informed Consent Statement: Not applicable.

Data Availability Statement: Not applicable.

Acknowledgments: The authors extend their appreciation to the deputyship for Research \& Innovation Ministry of Education in Saudi Arabia for funding this research work through the project number (IFP-2020-06).

Conflicts of Interest: The authors declare no conflict of interest.

\section{Nomenclature}

Symbols
$A$
$A_{g}$
$A D$
$A_{p v}$
$A_{t t}$
$A_{w i n d}$
$C$
$C_{B a t t e r y}$
$C_{p}$
$C V_{b i o}$
$D O D$
$E_{l}$
$F_{d g}$
$F C_{d g}$
$I$
$i_{r}$
$N$
$N O C T$
$N P C$
$O M$
$P_{d g}$
$P_{f}$
$P_{b g}$
$P_{B M}$
$P_{p v}$
$P_{r}$
$P_{r e}$
$P_{w}$

Availability index

Coefficient of consumption curve $(\mathrm{a}=0.246 \mathrm{~L} / \mathrm{kW})$

Daily autonomy of battery (day)

Area covered by the PV panels $\left(\mathrm{m}^{2}\right)$

Cross-sectional area of the tidal $\left(\mathrm{m}^{2}\right)$

Swept area by the wind turbine $\left(\mathrm{m}^{2}\right)$

Capital Cost (\$)

Capacity of the Battery (kWh)

Maximum power coefficient (\%)

Calorific value of the organic material $(\mathrm{MJ} / \mathrm{kg}$ )

Depth of Discharge (\%)

Load demand $(\mathrm{kWh})$

Fuel consumption of diesel $(\mathrm{L} / \mathrm{h})$

Fuel Cost for one year (\$/Year)

Solar irradiation $\left(\mathrm{kW} / \mathrm{m}^{2}\right)$

Interest rate $(\%)$

project lifetime (year)

Nominal operating cell temperature $\left({ }^{\circ} \mathrm{C}\right)$

Net Present Cost (\$)

Maintenance and operation (\$)

Rated power of the diesel generator $(\mathrm{kW})$

Fuel price (\$/L)

Generated power of the biogas plant $(\mathrm{kW})$

Biomass power $(\mathrm{kW})$

Output power of the PV $(\mathrm{kW})$

Rated power (kW)

Power from renewable energy systems

Annual working of biomass ( $\mathrm{kWh} /$ Year) $\eta_{b} \quad$ Efficiency of the battery (\%)

$\eta_{\text {bio }} \quad$ Efficiency of the biomass system (\%)

$\eta_{\text {inv }} \quad$ Efficiency of the inverter (\%)

$\eta_{p v} \quad$ Efficiency of the PV system (\%)

$\eta_{r} \quad$ Reference efficiency of PV panels (\%)

$P_{\text {wind }} \quad$ Output power of the wind turbine $(\mathrm{kW})$

$R \quad$ Replacement Cost (\$)

$T \quad$ Temperature $\left({ }^{\circ} \mathrm{C}\right)$

$\mathrm{T}_{a} \quad$ Ambient temperature $\left({ }^{\circ} \mathrm{C}\right)$

Total $_{\text {bio }}$ Total available of biomass (ton/yr)

$T_{r} \quad$ Reference temperature of solar cell $\left({ }^{\circ} \mathrm{C}\right)$

$V \quad$ Wind speed (m/s)

$V_{c i} \quad$ Cut-in wind speed $(\mathrm{m} / \mathrm{s})$

$V_{c o} \quad$ Cut-out wind speed $(\mathrm{m} / \mathrm{s})$

$V_{r} \quad$ Rated wind speed $(\mathrm{m} / \mathrm{s})$

$B_{g} \quad$ Coefficient of consumption curve $(b=0.08415 \mathrm{~L} / \mathrm{kW})$

$\eta_{t} \quad$ Efficiency MPPT system (\%)

$\beta \quad$ Temperature coefficient $\left(0.004\right.$ to $\left.0.006{ }^{\circ} \mathrm{C}\right)$

$\rho \quad$ Air density $\left(\mathrm{Kg} / \mathrm{m}^{3}\right)$

$\lambda_{\text {bat }} \quad$ Initial cost of the battery system ( $\left.\$ / \mathrm{kWh}\right)$

$\lambda_{b g} \quad$ Biomass initial cost $(\$ / \mathrm{kW})$

$\lambda_{d g} \quad$ Diesel generator initial cost $(\$ / \mathrm{kW})$

$\lambda_{P V, W T}$ Initial cost of PV and WT $\left(\$ / \mathrm{m}^{2}\right)$

$\delta \quad$ Inflation rate $(\%)$

$\mu \quad$ Escalation rate (\%)

$\theta_{1} \quad$ Biomass annual fixed O\&M cost $(\$ / \mathrm{kW} /$ year $)$

$\theta_{2} \quad$ Biomass variable O\&M cost $(\$ / \mathrm{kW} \mathrm{h})$ 


$\begin{array}{llll}\text { Abbreviations } & \\ \text { AEFA } & \text { Artificial Electric Field Algorithm } & \text { HMGs } & \text { Hybrid Microgrid system } \\ \text { ACS } & \text { Annualized cost of the system } & \text { HSA } & \text { Harmony Search Algorithm } \\ \text { BESS } & \text { Battery Energy Storage System } & \text { IWO } & \text { Invasive Weed optimization Algorithm } \\ \text { BO } & \text { Bonobo Optimizer Algorithm } & \text { LCOE } & \text { Levelized Cost of Energy } \\ \text { BOQO } & \text { Quasi Oppositional BO Algorithm } & \text { LPSP } & \text { Loss of Power Supply Probability } \\ \text { COE } & \text { Cost of Energy } & \text { MOPSO } & \text { Multiple Objective Particle Swarm Optimization } \\ \text { CRF } & \text { Capital Recovery Factor } & \text { NPC } & \text { Net present cost } \\ \text { GWO } & \text { Grey Wolf Optimizer } & \text { PSO } & \text { Particle Swarm Optimization } \\ \text { HOMER } & \text { Hybrid Optimization of Multiple Energy Resources } & \text { PV } & \text { Photovoltaic } \\ \text { HRES } & \text { Hybrid Renewable Energy Systems } & \text { RF } & \text { Renewable Fraction } \\ \text { HHO } & \text { Harris Hawks Optimization } & \text { WT } & \text { Wind Turbine }\end{array}$

Appendix A

Appendix A.1. Algorithm of Artificial Electric Field

Anita and Yadav [35] were inspired by physical theorem, especially from the Coulomb's law in the electrostatic force, to propose a recent algorithm called the artificial electric field. The concepts of the electric field and charged particles give us a theory of attraction and repulsion between the charged particles. The AEFA algorithm is presented in Algorithm A1.

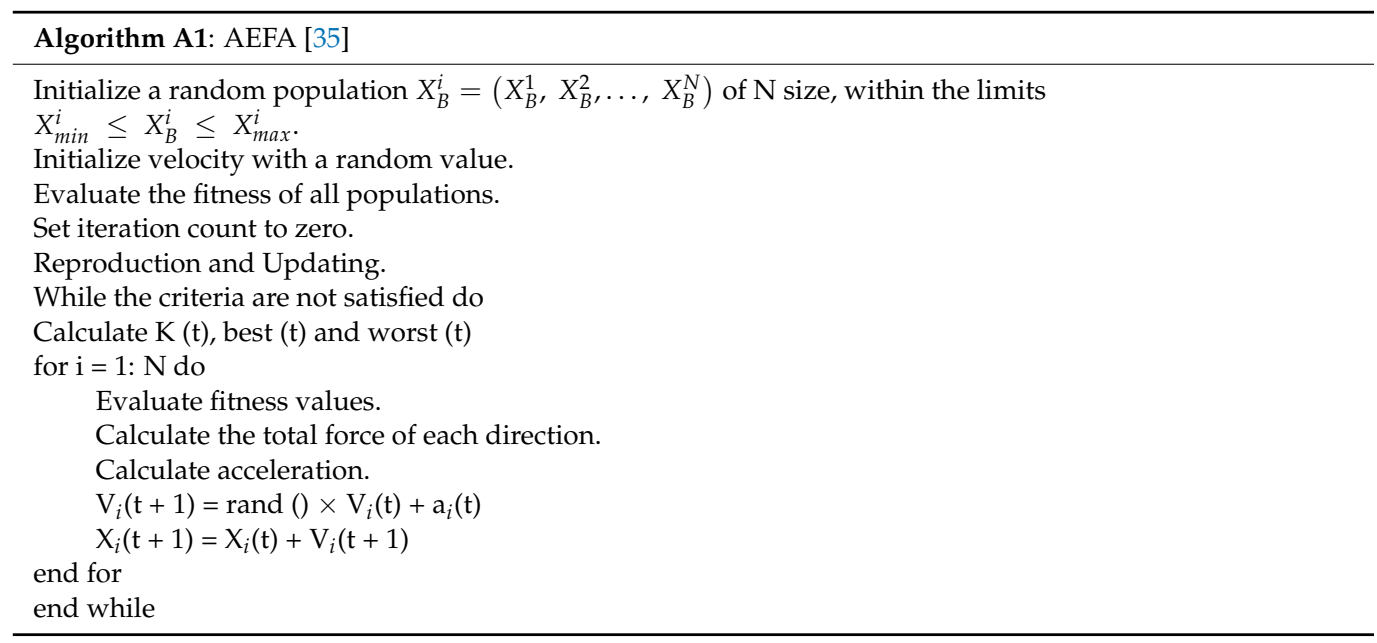

\section{Appendix A.2. Algorithm of Grey Wolf Optimizer}

Mirjalili et al. [36] proposed the grey wolf optimizer, which mimics the leadership hierarchy and hunting mechanism of grey wolves in nature. The four types of grey wolves are alpha, beta, delta, and omega. All types are employed to simulate the leadership hierarchy. Three essential steps of hunting are implemented: searching prey, encircling prey, and attacking prey. The pseudo-code of GWO algorithm is presented in Algorithm A2. 


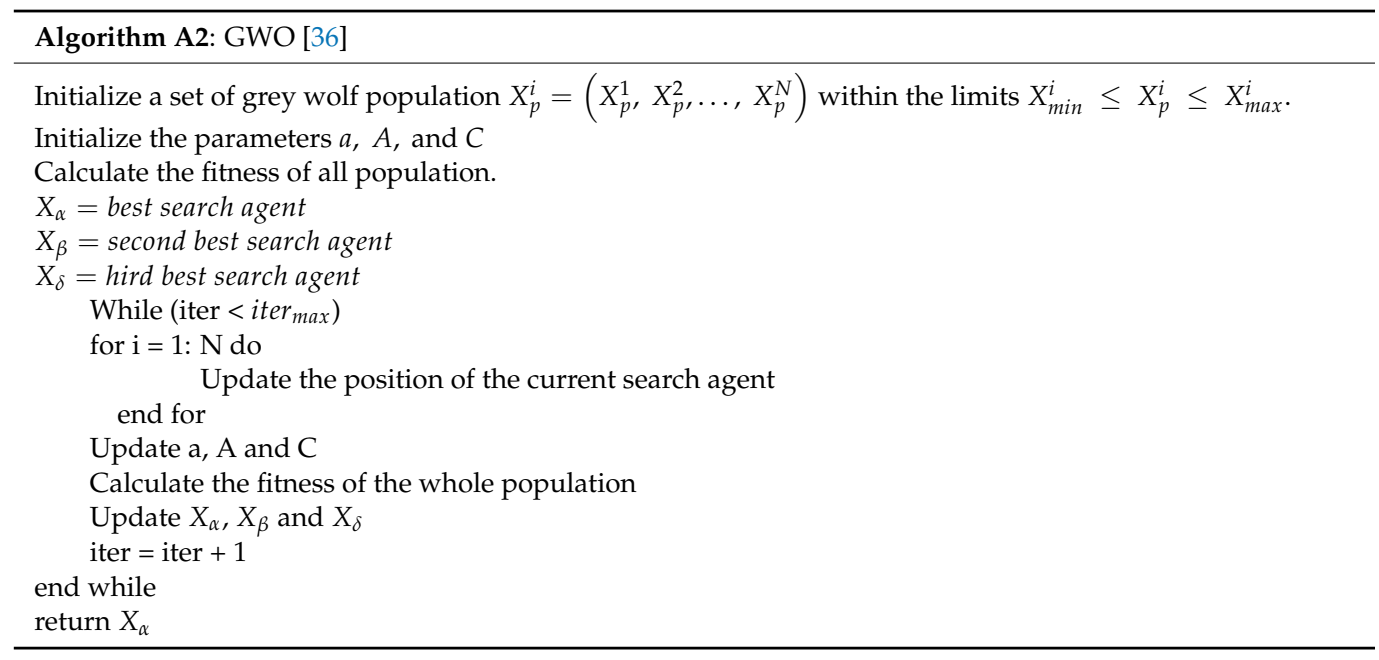

Appendix A.3. Algorithm Parameters

\begin{tabular}{ll}
\hline Algorithms & Parameters \\
\hline GPC & Gravity $=9.8 ;$ Angle of Ramp $=30 ;$ Minimum Friction = 1; Maximum Friction = 10; \\
AEFA & Substitution Probability $=0.5$. \\
GWO & $K_{0}=500 ; \alpha=30 ;$ Population size $=10 ;$ Maximum iteration $=100$ \\
\hline
\end{tabular}

\section{References}

1. Veilleux, G.; Potisat, T.; Pezim, D.; Ribback, C.; Ling, J.; Krysztofiński, A.; Ahmed, A.; Papenheim, J.; Pineda, A.M.; Sembian, S.; et al. Techno-economic analysis of microgrid projects for rural electrification: A systematic approach to the redesign of Koh Jik off-grid case study. Energy Sustain. Dev. 2020, 54, 1-13. [CrossRef]

2. Klemm, C.; Vennemann, P. Modeling and optimization of multi-energy systems in mixed-use districts: A review of existing methods and approaches. Renew. Sustain. Energy Rev. 2021, 135, 110206. [CrossRef]

3. Alzahrani, A.M.; Zohdy, M.; Yan, B. An Overview of Optimization Approaches for Operation of Hybrid Distributed Energy Systems with Photovoltaic and Diesel Turbine Generator. Electr. Power Syst. Res. 2021, 191, 106877. [CrossRef]

4. Bukar, A.L.; Tan, C.W. A review on stand-alone photovoltaic-wind energy system with fuel cell: System optimization and energy management strategy. J. Clean. Prod. 2019, 221, 73-88. [CrossRef]

5. Roy, A.; Auger, F.; Olivier, J.-C.; Schaeffer, E.; Auvity, B. Design, Sizing, and Energy Management of Microgrids in Harbor Areas: A Review. Energies 2020, 13, 5314. [CrossRef]

6. Babatunde, O.M.; Munda, J.L.; Hamam, Y. A Comprehensive State-of-the-Art Survey on Hybrid Renewable Energy System Operations and Planning. IEEE Access 2020, 8, 75313-75346. [CrossRef]

7. Singh, R.; Bansal, R.C. Review of HRESs based on storage options, system architecture and optimisation criteria and methodologies. Iet Renew. Power Gener. 2018, 12, 747-760. [CrossRef]

8. Fathy, A.; Kaaniche, K.; Alanazi, T.M. Recent Approach Based Social Spider Optimizer for Optimal Sizing of Hybrid PV/Wind/Battery/Diesel Integrated Microgrid in Aljouf Region. IEEE Access 2020, 8, 57630-57645. [CrossRef]

9. Rezk, H.; Kanagaraj, N.; Al-Dhaifallah, M. Design and Sensitivity Analysis of Hybrid Photovoltaic-Fuel-Cell-Battery System to Supply a Small Community at Saudi NEOM City. Sustainability 2020, 12, 3341. [CrossRef]

10. Ramli, M.A.M.; Hiendro, A.; Al-Turki, Y.A. Techno-economic energy analysis of wind/solar hybrid system: Case study for western coastal area of Saudi Arabia. Renew. Energy 2016, 91, 374-385. [CrossRef]

11. Alharthi, Y.; Siddiki, M.; Chaudhry, G. Resource Assessment and Techno-Economic Analysis of a Grid-Connected Solar PV-Wind Hybrid System for Different Locations in Saudi Arabia. Sustainability 2018, 10, 3690. [CrossRef]

12. Kharrich, M.; Kamel, S.; Abdeen, M.; Mohammed, O.H.; Akherraz, M.; Khurshaid, T.; Rhee, S.-B. Developed Approach Based on Equilibrium Optimizer for Optimal Design of Hybrid PV/Wind/Diesel/Battery Microgrid in Dakhla, Morocco. IEEE Access 2021, 9, 13655-13670. [CrossRef]

13. Barbaro, M.; Castro, R. Design optimisation for a hybrid renewable microgrid: Application to the case of Faial island, Azores archipelago. Renew. Energy 2020, 151, 434-445. [CrossRef]

14. Kharrich, M.; Mohammed, O.H.; Alshammari, N.; Akherraz, M. Multi-objective optimization and the effect of the economic factors on the design of the microgrid hybrid system. Sustain. Cities Soc. 2021, 65, 102646. [CrossRef]

15. Yoshida, Y.; Farzaneh, H. Optimal Design of a Stand-Alone Residential Hybrid Microgrid System for Enhancing Renewable Energy Deployment in Japan. Energies 2020, 13, 1737. [CrossRef] 
16. Elkadeem, M.R.; Wang, S.; Sharshir, S.W.; Atia, E.G. Feasibility analysis and techno-economic design of grid-isolated hybrid renewable energy system for electrification of agriculture and irrigation area: A case study in Dongola, Sudan. Energy Convers. Manag. 2019, 196, 1453-1478. [CrossRef]

17. Odou, O.D.T.; Bhandari, R.; Adamou, R. Hybrid off-grid renewable power system for sustainable rural electrification in Benin. Renew. Energy 2020, 145, 1266-1279. [CrossRef]

18. Curto, D.; Favuzza, S.; Franzitta, V.; Musca, R.; Navarro Navia, M.A.; Zizzo, G. Evaluation of the optimal renewable electricity mix for Lampedusa island: The adoption of a technical and economical methodology. J. Clean. Prod. 2020, 263, 121404. [CrossRef]

19. Ciavarella, R.; Graditi, G.; Valenti, M.; Pinnarelli, A.; Barone, G.; Vizza, M.; Menniti, D.; Sorrentino, N.; Brusco, G. Modeling of an Energy Hybrid System Integrating Several Storage Technologies: The DBS Technique in a Nanogrid Application. Sustainability 2021, 13, 1170. [CrossRef]

20. Crainz, M.; Curto, D.; Franzitta, V.; Longo, S.; Montana, F.; Musca, R.; Sanseverino, E.R.; Telaretti, E. Flexibility Services to Minimize the Electricity Production from Fossil Fuels. A Case Study in a Mediterranean Small Island. Energies 2019, $12,3492$. [CrossRef]

21. Dawood, F.; Shafiullah, G.; Anda, M. Stand-Alone Microgrid with 100\% Renewable Energy: A Case Study with Hybrid Solar PV-Battery-Hydrogen. Sustainability 2020, 12, 2047. [CrossRef]

22. Corti, F.; Laudani, A.; Lozito, G.M.; Reatti, A. Computationally Efficient Modeling of DC-DC Converters for PV Applications. Energies 2020, 13, 5100. [CrossRef]

23. Khan, A.; Javaid, N. Jaya Learning-Based Optimization for Optimal Sizing of Stand-Alone Photovoltaic, Wind Turbine, and Battery Systems. Engineering 2020, 6, 812-826. [CrossRef]

24. Makhdoomi, S.; Askarzadeh, A. Optimizing operation of a photovoltaic/diesel generator hybrid energy system with pumped hydro storage by a modified crow search algorithm. J. Energy Storage 2020, 27, 101040. [CrossRef]

25. Kharrich, M.; Mohammed, O.H.; Kamel, S.; Selim, A.; Sultan, H.M.; Akherraz, M.; Jurado, F. Development and Implementation of a Novel Optimization Algorithm for Reliable and Economic Grid-Independent Hybrid Power System. Appl. Sci. 2020, 10, 6604. [CrossRef]

26. Abo-Elyousr, F.K.; Elnozahy, A. Bi-objective economic feasibility of hybrid micro-grid systems with multiple fuel options for islanded areas in Egypt. Renew. Energy 2018, 128, 37-56. [CrossRef]

27. Heydari, A.; Askarzadeh, A. Optimization of a biomass-based photovoltaic power plant for an off-grid application subject to loss of power supply probability concept. Appl. Energy 2016, 165, 601-611. [CrossRef]

28. Guangqian, D.; Bekhrad, K.; Azarikhah, P.; Maleki, A. A hybrid algorithm-based optimization on modeling of grid independent biodiesel-based hybrid solar/wind systems. Renew. Energy 2018, 122, 551-560. [CrossRef]

29. Sawle, Y.; Gupta, S.C.; Bohre, A.K. Socio-techno-economic design of hybrid renewable energy system using optimization techniques. Renew. Energy 2018, 119, 459-472. [CrossRef]

30. Ramli, M.A.M.; Bouchekara, H.R.E.H.; Alghamdi, A.S. Optimal sizing of PV/wind/diesel hybrid microgrid system using multi-objective self-adaptive differential evolution algorithm. Renew. Energy 2018, 121, 400-411. [CrossRef]

31. Movahediyan, Z.; Askarzadeh, A. Multi-objective optimization framework of a photovoltaic-diesel generator hybrid energy system considering operating reserve. Sustain. Cities Soc. 2018, 41, 1-12. [CrossRef]

32. Ghiasi, M. Detailed study, multi-objective optimization, and design of an AC-DC smart microgrid with hybrid renewable energy resources. Energy 2019, 169, 496-507. [CrossRef]

33. Harifi, S.; Mohammadzadeh, J.; Khalilian, M.; Ebrahimnejad, S. Giza Pyramids Construction: An ancient-inspired metaheuristic algorithm for optimization. Evol. Intell. 2020. [CrossRef]

34. SoDa Delivers Solar Radiation Data. Available online: http:/ /www.soda-pro.com/ (accessed on 5 February 2021).

35. Yadav, A. AEFA: Artificial electric field algorithm for global optimization. Swarm Evol. Comput. 2019, 48, 93-108.

36. Mirjalili, S.; Mirjalili, S.M.; Lewis, A. Grey wolf optimizer. Adv. Eng. Softw. 2014, 69, 46-61. [CrossRef] 